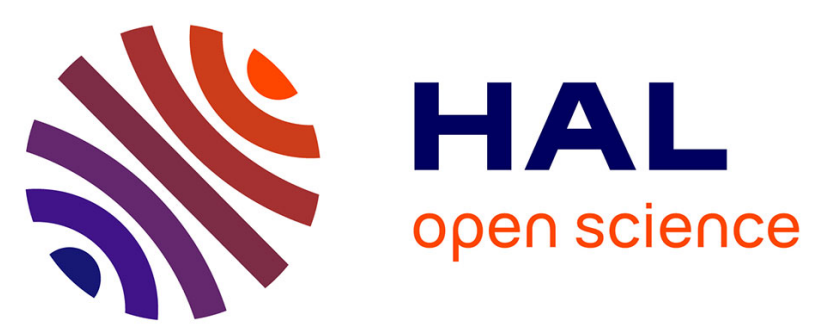

\title{
Reactivity of Hydrogen Peroxide with Br and I Atoms
} Camille Fortin, Sarah Khanniche, Dorra Khiri, Valerie Fèvre-Nollet, Patrick

Lebègue, Frédéric Cousin, Ivan Černušák, Florent Louis

\section{To cite this version:}

Camille Fortin, Sarah Khanniche, Dorra Khiri, Valerie Fèvre-Nollet, Patrick Lebègue, et al.. Reactivity of Hydrogen Peroxide with Br and I Atoms. Journal of Physical Chemistry A, 2018, Journal of Physical Chemistry. Part A, 122 (4), pp.1053-1063. 10.1021/acs.jpca.7b10318 . hal-02335081

\section{HAL Id: hal-02335081 https://hal.univ-lille.fr/hal-02335081}

Submitted on 16 Jul 2020

HAL is a multi-disciplinary open access archive for the deposit and dissemination of scientific research documents, whether they are published or not. The documents may come from teaching and research institutions in France or abroad, or from public or private research centers.
L'archive ouverte pluridisciplinaire HAL, est destinée au dépôt et à la diffusion de documents scientifiques de niveau recherche, publiés ou non, émanant des établissements d'enseignement et de recherche français ou étrangers, des laboratoires publics ou privés. 


\section{Reactivity of Hydrogen Peroxide with Br and I}

\section{Atoms}

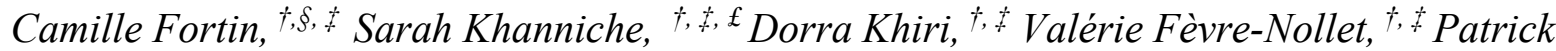
Lebègue, ${ }^{\dagger}, \dot{t}$ Frédéric Cousin, ${ }^{\S}, \dot{t}$ Ivan Černušák ${ }^{* \#}$, Florent Louis, $* \dot{t}, \dot{t}$

${ }^{\dagger}$ Univ. Lille, CNRS, UMR 8522 - PC2A - PhysicoChimie des Processus de Combustion et de l'Atmosphère, F-59000 Lille, France

§ Institut de Radioprotection et de Sûreté Nucléaire (IRSN), PSN-RES, Cadarache, St Paul Lez Durance, 13115, France

\# Department of Physical and Theoretical Chemistry, Faculty of Natural Sciences, Comenius University in Bratislava, Mlynská dolina CH1, 84215 Bratislava, Slovakia

$\$$ Laboratoire de Recherche Commun IRSN-CNRS-Lille1 "Cinétique Chimique, Combustion, Réactivité" (C3R), Cadarache, St Paul Lez Durance, 13115, France

${ }^{£}$ Present address: Department of Chemical Engineering, Massachusetts Institute of Technology, Cambridge, MA 02139, United States 


\begin{abstract}
The reaction mechanisms of $\mathrm{Br}$ and I atoms with $\mathrm{H}_{2} \mathrm{O}_{2}$ have been investigated using DFT and high-level $a b$ initio calculations. The $\mathrm{H}$-abstraction and $\mathrm{OH}$-abstraction channels were highlighted. The geometries of the stationary points were optimized at the B3LYP/aug-ccpVTZ level of theory and the energetics were recalculated with the coupled cluster theory. Spinorbit coupling for each halogenated species was also explicitly computed by employing the MRCI level of theory. Thermochemistry for $\mathrm{HOBr}$ and HOI has been revised and updated standard enthalpies of formation at $298 \mathrm{~K}$ for $\mathrm{HOBr}$ and $\mathrm{HOI}$ are the following : $\Delta_{\mathrm{f}} H^{\circ}{ }_{298 \mathrm{~K}}$ $(\mathrm{HOBr})=(-66.2 \pm 4.6) \mathrm{kJ} \mathrm{mol}^{-1}$ and $\Delta_{\mathrm{f}} H^{\circ}{ }_{298 \mathrm{~K}}(\mathrm{HOI})=(-66.8 \pm 4.7) \mathrm{kJ} \mathrm{mol}^{-1}$. The rate constants have been estimated using canonical transition state theory (TST) with an asymmetrical Eckart tunneling correction over a wide temperature range $(250-2500 \mathrm{~K})$. For the direct abstraction mechanism, the overall rate constant at $300 \mathrm{~K}$ was predicted to be $1.53 \times 10^{-18}$ and $2.12 \times 10^{-23}$ $\mathrm{cm}^{3}$ molecule $\mathrm{e}^{-1} \mathrm{~s}^{-1}$ for the $\mathrm{Br}+\mathrm{H}_{2} \mathrm{O}_{2}$ and $\mathrm{I}+\mathrm{H}_{2} \mathrm{O}_{2}$ reactions respectively.

The modified Arrhenius parameters have been estimated for the overall reactions:

$k_{\mathrm{Br}+\mathrm{H}_{2} \mathrm{O}_{2}}(T)=7.39 \times 10^{-23} \times T^{3.59} \exp \left(-26.41\left(\mathrm{~kJ} \mathrm{~mol}^{-1}\right) / \mathrm{R} T\right)$

and $k_{\mathrm{I}+\mathrm{H}_{2} \mathrm{O}_{2}}(T)=3.12 \times 10^{-20} \times T^{2.95} \exp \left(-60.23\left(\mathrm{~kJ} \mathrm{~mol}^{-1}\right) / \mathrm{R} T\right)$.
\end{abstract}

\title{
1. Introduction
}

Because of their possible implications in the destruction of the stratospheric ozone layer ${ }^{1}$, attention has been paid to the reactions of $\mathrm{Cl}$ and $\mathrm{Br}$ with $\mathrm{H}_{2} \mathrm{O}_{2}{ }^{2-10}$ (Table 1). Hydrogen peroxide is of atmospheric and combustion interests ${ }^{11}$ as it acts as a precursor for key species such as $\mathrm{HO}_{2}$ and $\mathrm{OH}$ radicals. For instance, the $\mathrm{H}-$ and $\mathrm{O}(\mathrm{H})$ - abstractions of hydrogen peroxide by halogen atoms $(\mathrm{Cl}, \mathrm{Br}, \mathrm{I})$ produces hydroperoxyl (R1) and hydroxyl radicals (R2).

$$
\mathrm{X}+\mathrm{H}_{2} \mathrm{O}_{2} \rightarrow \mathrm{HX}+\mathrm{HO}_{2}
$$




$$
\mathrm{X}+\mathrm{H}_{2} \mathrm{O}_{2} \rightarrow \mathrm{HOX}+\mathrm{OH}
$$

Extensive experimental studies of the $\mathrm{Cl}+\mathrm{H}_{2} \mathrm{O}_{2} \rightarrow \mathrm{HCl}+\mathrm{HO}_{2}$ reaction can be found in the literature (Table 1). Watson et al. ${ }^{2}$ and Michael et al. ${ }^{3}$ employed flash photolysis-resonance fluorescence to determine the reaction rate constant at $300 \mathrm{~K}$ and for temperatures ranging from 265-400 K, respectively. Leu and DeMore ${ }^{4}$ and Poulet et al. ${ }^{5}$ studied the kinetics of the reaction

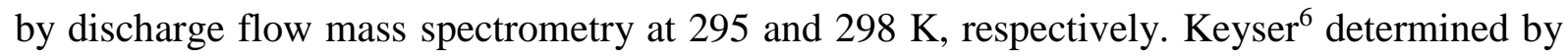
the discharge flow resonance fluorescence technique the rate constant at $298 \mathrm{~K}$ and the Arrhenius expression over the temperature range $298-424 \mathrm{~K}$. Marouani et al. ${ }^{7}$ reported for the first time ab initio calculations of the $\mathrm{Cl}+\mathrm{H}_{2} \mathrm{O}_{2} \rightarrow \mathrm{HCl}+\mathrm{HO}_{2}$ and $\mathrm{Cl}+\mathrm{H}_{2} \mathrm{O}_{2} \rightarrow \mathrm{HOCl}+\mathrm{OH}$ reactions using the post Hartree-Fock MCQDPT2//CASSCF approach and the aug-cc-pVTZ basis set. The kinetics of both reactions was investigated using transition state theory over a wide temperature range (200-2500 K). The H- abstraction pathway dominates for temperatures below $1500 \mathrm{~K}$ while the $\mathrm{OH}$ - abstraction pathway significantly contributes for higher temperatures.

The reaction of $\mathrm{Br}$ with $\mathrm{H}_{2} \mathrm{O}_{2}$ has also been studied previously over a narrow temperature range (Table 1) and yet large discrepancies remain. Leu ${ }^{8}$ and Posey et al. ${ }^{9}$ determined upper limits for the reaction rate constants over the temperature range $298-417 \mathrm{~K}$ and at $298 \mathrm{~K}$, respectively. Heneghan and Benson ${ }^{10}$ employed a very low pressure reactor to investigate the rate constants and product formation of the $\mathrm{Br}+\mathrm{H}_{2} \mathrm{O}_{2}$ reaction in the range of $300-350 \mathrm{~K}$. They found that $k(300 \mathrm{~K})=(1.3 \pm 0.45) \times 10^{-14} \mathrm{~cm}^{3}$ molecule ${ }^{-1} \mathrm{~s}^{-1}$ and $k(350 \mathrm{~K})=(3.75 \pm 1.1) \times 10^{-}$ ${ }^{14} \mathrm{~cm}^{3}$ molecule $\mathrm{e}^{-1} \mathrm{~s}^{-1}$. The measured rate constants were found to be significantly faster than the upper limit values reported previously $y^{8,9}$ and Heneghan and Benson ${ }^{10}$ concluded that future studies should be carried out on the kinetics of the $\mathrm{Br}+\mathrm{H}_{2} \mathrm{O}_{2}$ reaction.

To the best of our knowledge, there is no experimental nor theoretical investigation of the I+ $\mathrm{H}_{2} \mathrm{O}_{2}$ reaction system reported in the literature. However, besides it significant role in the 
depletion of ozone from the troposphere, ${ }^{12-14}$ reactivity of iodine is also relevant for nuclear safety. ${ }^{15-17}$ As a matter as fact, iodine species can be found inside the containment of a pressurized water reactor, in the case of a core melt accident.

Iodine speciation and physical form are key issues to better consider radiological consequences of a nuclear accident. To accurately consider the high reactivity of iodine in the dispersion crisis tools, kinetic parameters are needed as input parameters in chemistry-transport models. Such data are relatively scarce for iodine-containing species and some of them exhibit large uncertainties. Quantum chemistry methods allow obtaining reliable quantitative data within chemical accuracy $\left( \pm 1 \mathrm{~kJ} \mathrm{~mol}^{-1}\right)$ as shown in our previous studies dealing with atmospheric iodine chemistry. ${ }^{18-24}$ In this article, we will present $a b$ initio calculations of the reaction mechanisms of the $\mathrm{H}$ - and $\mathrm{OH}-$ abstraction of $\mathrm{H}_{2} \mathrm{O}_{2}$ by $\mathrm{Br}$ and $\mathrm{I}$ atoms. The rate constants in the temperature range of $250-2500 \mathrm{~K}$ were subsequently determined by the transition state theory (TST). This is the first time that the reactions of bromine and iodine with hydrogen peroxide are theoretically investigated. Details on the computational tools employed are provided in Section 2 and the results are exposed and discussed in Section 3. 
Table 1. Literature Rate Parameters for the $\mathrm{X}+\mathrm{H}_{2} \mathrm{O}_{2}$ Reactions $(\mathrm{X}=\mathrm{Cl}$ and $\mathrm{Br})$

\begin{tabular}{|c|c|c|c|c|c|c|}
\hline Reactant & $\begin{array}{c}\mathrm{A} \\
\left(\mathrm{cm}^{3} \text { molecule }^{-1} \mathrm{~s}^{-1}\right)\end{array}$ & $\begin{array}{c}\mathrm{E}_{\mathrm{a}} \\
\left(\mathrm{kJ} \mathrm{mol}^{-1}\right)\end{array}$ & $\begin{array}{c}k \\
\left(\mathrm{~cm}^{3} \text { molecule }{ }^{-1} \mathrm{~s}^{-1}\right)\end{array}$ & $\mathrm{T}(\mathrm{K})$ & method & ref \\
\hline \multirow[t]{9}{*}{$\mathrm{Cl}+\mathrm{H}_{2} \mathrm{O}_{2}$} & & & $(5.8 \pm 2.0) \times 10^{-13}$ & 300 & experiment $^{\mathrm{a}}$ & ${ }^{2}$ Watson et al., 1976 \\
\hline & & & $(6.2 \pm 1.5) \times 10^{-13}$ & 295 & experiment ${ }^{\mathrm{b}}$ & ${ }^{4}$ Leu et DeMore, 1976 \\
\hline & & & $(3.14 \pm 0.56) \times 10^{-13}$ & 298 & experiment ${ }^{\mathrm{c}}$ & ${ }^{3}$ Michael et al., 1977 \\
\hline & $(1.24 \pm 0.74) \times 10^{-12}$ & 3.19 & & $265-400$ & & \\
\hline & & & $(4.0 \pm 0.4) \times 10^{-13}$ & 298 & experiment ${ }^{\mathrm{b}}$ & ${ }^{5}$ Poulet et al., 1978 \\
\hline & & & $(4.1 \pm 0.2) \times 10^{-13}$ & 298 & experiment ${ }^{\mathrm{d}}$ & ${ }^{6}$ Keyser, 1980 \\
\hline & $(1.05 \pm 0.31) \times 10^{-11}$ & 8.16 & & $298-424$ & & \\
\hline & & & $3.16 \times 10^{-14}$ & 298 & theory ${ }^{\mathrm{e}}$ & ${ }^{7}$ Marouani et al., 2009 \\
\hline & & & $2.87 \times 10^{-11}$ & 1500 & & \\
\hline \multirow[t]{5}{*}{$\mathrm{Br}+\mathrm{H}_{2} \mathrm{O}_{2}$} & & & $<1.5 \times 10^{-15}$ & 298 & experiment $\mathrm{t}^{\mathrm{b}}$ & ${ }^{8} \mathrm{Leu}, 1980$ \\
\hline & & & $<3.0 \times 10^{-15}$ & 417 & & \\
\hline & & & $<2 \times 10^{-15}$ & 298 & experiment $\mathrm{t}^{\mathrm{b}}$ & ${ }^{9}$ Posey et al/, 1981 \\
\hline & & & $(1.3 \pm 0.45) \times 10^{-14}$ & 300 & experiment $^{\mathrm{f}}$ & ${ }^{10}$ Heneghan and Benson, 1983 \\
\hline & & & $(3.75 \pm 1.1) \times 10^{-14}$ & 350 & & \\
\hline
\end{tabular}

a thermal/resonance fluorescence. ${ }^{b}$ electron beam/mass spectrometry. ${ }^{c}$ flash photolysis/resonance fluorescence. ${ }^{d}$ electron beam/resonance fluorescence. ${ }^{\mathrm{e}}$ MCQDPT2//CASSCF approach with the aug-cc-pVTZ basis set. ${ }^{\mathrm{f}}$ thermal/mass spectrometry. 


\section{Computational methods}

The geometries of all stationary points along the potential energy surface (PES) were optimized with the B3LYP density-functional theory ${ }^{25}$ (B3LYP) in conjunction with the augmented correlation consistent polarized triple zeta ${ }^{26}$ (aug-cc-pVTZ) basis set for Br, O, and $\mathrm{H}$ atoms and with the aug-cc-pVTZ-PP basis set of Peterson et al. ${ }^{27}$ for the 25 valence electrons of the iodine atom (this basis set will be written without the PP term in the rest of the paper) while the core electrons were described by the pseudopotential ECP28MDF. Vibrational wavenumbers and zero-point energies (ZPE) were determined at the B3LYP/aug-cc-pVTZ level of theory and the appropriate scaling factor ${ }^{28}(0.968)$ was utilized. Intrinsic reaction coordinate (IRC) $)^{29-31}$ calculations at the B3LYP/aug-cc-pVTZ levels as implemented by default in Gaussian09 were performed in order to confirm the connection of the transition states with minima. All previous calculations were performed using Gaussian 09 (D.01). ${ }^{32}$

Single-point energies were calculated at a higher level of theory using Molpro 2015 program package. ${ }^{33}$ Coupled cluster theory calculations were carried out on the geometries previously optimized in combination with the weighted core-valence basis set ${ }^{34,35}$ aug-cc-pwCVnZ $(n=\mathrm{T}$, Q) basis sets for $\mathrm{Br}, \mathrm{O}$, and $\mathrm{H}$ atoms and the aug-cc-pwCVnZ-PP $(n=\mathrm{T}, \mathrm{Q})$ basis sets of Peterson et l. $^{27}$ for the iodine atom. The complete basis set (CBS) limit was extrapolated for the $\operatorname{CCSD}(\mathrm{T})$ energies with the following two-point extrapolation of Min et al. ${ }^{36}$ :

$$
E_{C B S}(n)=\frac{E(n) \times \mathrm{n}^{3}-E(n-1) \times(\mathrm{n}-1)^{3}}{\mathrm{n}^{3}-(\mathrm{n}-1)^{3}}(n=4)
$$

with $E_{\mathrm{CBS}}$ is the CBS limit for the $\operatorname{CCSD}(\mathrm{T})$ energies and $n$ is the cardinal number of the weighted core-valence basis set $(3=$ awCVTZ, $4=$ awCVQZ).

Several corrections were then applied to the $\operatorname{CCSD}(\mathrm{T}) / \mathrm{CBS}$ energies. The core-valence $(\mathrm{CV})$ calculations were performed at the $\operatorname{CCSD}(\mathrm{T})$ level of theory using weighted core-valence basis set. The CV correction is then taken as the difference in energy between the valence electron 
correlation calculation and that with the nearest core electrons included. The CBS limit extrapolation using formula (1) was also applied in the core-valence calculations. The scalar relativistic corrections (SR) were performed at the $\operatorname{CCSD(T)/Douglas-Kroll-Hess~}{ }^{37-40}$ level with the aug-cc-pVTZ-DK basis sets for compounds containing Br. For the iodinated species, the pseudopotential already considers the scalar relativistic correction on I. For these compounds, this correction accounts for scalar relativistic effects primarily for atoms other than I and it was evaluated from the expectation values for the two dominant terms in the Breit-Pauli Hamiltonian (the mass-velocity and one-electron Darwin ${ }^{41}$ (MVD) corrections) using the CISD/aug-cc-pVTZ level of theory. Previous works on iodine species of Dixon et al. ${ }^{42,43}$ shows that when applying a MVD correction to an energy, which already includes most of the relativistic effects via the RECP, the double counting of the relativistic effect on iodine is small.

The spin-orbit coupling $(\mathrm{SO})^{44,45}$ calculations, for the bromine- and iodine-containing species, were carried out at the MRCI/aug-cc-pVTZ level of theory taking the CASSCF wave function as a reference. For all molecular complexes and transition states, the active space contains 21 active electrons distributed in 14 active orbitals for $\mathrm{Br}$ and I intermediate species, respectively. The active electrons correspond to: (i) 1 electron of the 1 s orbital of each $\mathrm{H}$ atom, (ii) 6 electrons of the $2 \mathrm{~s}$ and $2 p$ orbitals of each oxygen, and (iii) 7 electrons of the $4 \mathrm{~s}$ and $4 p$ orbitals of $\mathrm{Br}$ atom or of the $5 \mathrm{~s}$ and $5 \mathrm{p}$ orbitals of I atom.

The enthalpy at $0 \mathrm{~K}$ is calculated from eq 2 including different energy contributions:

$$
H_{0 \mathrm{~K}}=E_{\mathrm{CBS}}+E_{\mathrm{ZPE}}+E_{\mathrm{CV}}+E_{\mathrm{SR}}+E_{\mathrm{SO}}
$$

The canonical transition state theory $(\mathrm{TST})^{46-48}$ with the one-dimensional asymmetrical Eckart tunneling correction ${ }^{49}$ is used in the calculation of the rate constants over a wide temperature range $(250-2500 \mathrm{~K})$. This method is adequate in our case because of the presence of small or moderate tunneling corrections. These calculations are carried out with the GPOP $\operatorname{program}^{50}$ 
The rate constants have been calculated for the direct mechanism which considers the reaction from the reactants to the products using the following expression:

$$
k(T)=\Gamma(T) \times \frac{k_{B} T}{h} \times \frac{Q_{\mathrm{TS}}}{Q_{\mathrm{X}} Q_{\mathrm{H}_{2} \mathrm{O}_{2}}} \times \exp \left(-\frac{E_{T S}-E_{X}-E_{\mathrm{H}_{2} O_{2}}}{k_{B} T}\right)
$$

where $\Gamma(T)$ corresponds to the transmission coefficient used for the tunneling correction at $T$, $k_{B}$ is Boltzmann's constant, and h is Planck's constant. $Q_{\mathrm{TS}}, Q_{\mathrm{X}}$, and $Q_{\mathrm{H} 2 \mathrm{O} 2}$ are the total partition functions for the TS and the reactants $\left(\mathrm{X}\right.$ and $\left.\mathrm{H}_{2} \mathrm{O}_{2}\right)$ at the temperature $T$. $E_{\mathrm{TS}}, E_{\mathrm{X}}$, and $E_{\mathrm{H} 2 \mathrm{O} 2}$ are the total energies including the zero-point energy, the CV, the SOC, and the SR corrections at $0 \mathrm{~K}$.

The rigid-rotor harmonic-oscillator approximation has been used to treat the vibrational modes except modes which correspond to internal rotations. They were treated as hindered rotors. As implemented in the GPOP program, ${ }^{50}$ their partition functions were computed using the Pitzer-Gwinn approximation. In the $\mathrm{H}_{2} \mathrm{O}_{2}$ structure, the first low-frequency vibrational mode, which corresponds to the rotation of the $\mathrm{OH}$ subsystem around the axis $(\mathrm{O} \ldots \mathrm{O})$ is identified as hindered rotor $\left(362 \mathrm{~cm}^{-1}\right)$. The corresponding computed potential curve was symmetrical involving a symmetry number 2 for the internal rotation. For both $\mathrm{Br}+\mathrm{H}_{2} \mathrm{O}_{2}$ and $\mathrm{I}+\mathrm{H}_{2} \mathrm{O}_{2}$ reactions, we identified one low-frequency vibrational mode as hindered rotation in the MCR and also in the $\mathrm{H}-$ and $\mathrm{OH}$-abstraction TS and MCP structures (in all cases, it corresponds to the third mode). In this case, the corresponding calculated potential curves were not symmetrical implying a symmetry number 1 for the internal rotation. In the MCR, MCP ${ }_{\text {Habs, }}$ and $\mathrm{TS}_{\mathrm{Habs}}$ structures of the $\mathrm{Br}+\mathrm{H}_{2} \mathrm{O}_{2}$, it corresponds to 207,147 , and $356 \mathrm{~cm}^{-1}$, respectively, it matches the rotation of the $\mathrm{OH}$ subsystem around the axis $(\mathrm{O} \ldots \mathrm{O})$. In the MCPoHabs and

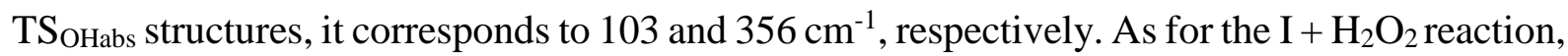
the low frequency vibrational modes treated as hindered rotor in the $\mathrm{MCR}, \mathrm{MCP}_{\mathrm{Habs}}$, and $\mathrm{TS}_{\mathrm{Habs}}$ structures are 207,113 , and $317 \mathrm{~cm}^{-1}$, respectively. In the $\mathrm{MCP}_{\mathrm{OHabs}}$ and TSOHabs structures, it corresponds to 138 and $312 \mathrm{~cm}^{-1}$, respectively. 


\section{Results and Discussion}

The structures of reactants and products of $\mathrm{X}+\mathrm{H}_{2} \mathrm{O}_{2}(\mathrm{X}=\mathrm{Br}, \mathrm{I})$ reactions are presented in Figure 1 along with the main geometric parameters and their SO corrections. The rotational constants, scaled vibrational frequencies, and ZPEs are given in Table 2. The SO splitting obtained in this work for $\mathrm{Br}$ atom with 7 active electrons in 9 active orbitals leads to the value of $3549 \mathrm{~cm}^{-1}$. This is in good agreement with the experimental result reported by Moore ${ }^{51}(3685$ $\left.\mathrm{cm}^{-1}\right)$ and the theoretical value of Nicklass et al. ${ }^{52}\left(3583 \mathrm{~cm}^{-1}\right)$ obtained from CISD/cc-pCV5Z calculation with 7 active electrons in 4 active orbitals. For I atom, our calculation with 7 active electrons in 9 active orbitals giving a splitting of $7730 \mathrm{~cm}^{-1}$, which is in quite good agreement with experimental splitting of $7603.15 \mathrm{~cm}^{-1}$ reported by Moore. ${ }^{51}$ The SOC for Br $(-14.00 \mathrm{~kJ}$ $\left.\mathrm{mol}^{-1}\right)$ is approximately half the value of iodine $\left(-30.54 \mathrm{~kJ} \mathrm{~mol}^{-1}\right)$. The calculated SOC for HI with 8 active electrons in 6 active orbitals $\left(-2.20 \mathrm{~kJ} \mathrm{~mol}^{-1}\right)$ is very similar to the theoretical value obtained by Mečiarová et al. ${ }^{20}\left(-2.30 \mathrm{~kJ} \mathrm{~mol}^{-1}\right)$ using the CASPT2/RASSI method and is also in excellent agreement with the $\operatorname{CCSD}(\mathrm{T}) / \mathrm{CBS}$ value given by Feller et al. ${ }^{53}\left(-2.30 \mathrm{~kJ} \mathrm{~mol}^{-1}\right)$. For $\mathrm{HBr}$, the SOC $\left(-0.61 \mathrm{~kJ} \mathrm{~mol}^{-1}\right)$ obtained with 8 active electrons in 10 active orbitals is in quite good agreement with the $\operatorname{CCSD}(\mathrm{T}) / \mathrm{CBS}$ value of Feller et al. ${ }^{53}$ $\left(-0.49 \mathrm{~kJ} \mathrm{~mol}^{-1}\right)$. The computed SOC for HOI with 14 active electrons in 9 active orbitals $\left(-5.51 \mathrm{~kJ} \mathrm{~mol}^{-1}\right)$ is in excellent agreement with the calculated value $\left(-5.94 \mathrm{~kJ} \mathrm{~mol}^{-1}\right)$ obtained by Šulková et al. ${ }^{54}$ using CASPT2/RASSI level of theory with 10 active electrons in 7 active orbitals. Our value is larger than the one given by Stevens et al. ${ }^{55}\left(-1.69 \mathrm{~kJ} \mathrm{~mol}^{-1}\right)$ using the one-electron effective spin-orbit Hamiltonian with 6 active electrons in 5 active orbitals. This difference results from the different used level of theory as well as the size of the active space. The SOC for $\mathrm{HOBr}\left(-0.92 \mathrm{~kJ} \mathrm{~mol}^{-1}\right)$ is obtained with 14 active electrons in 9 active orbitals. The SOC for $\mathrm{HBr}\left(-0.61 \mathrm{~kJ} \mathrm{~mol}^{-1}\right)$ and $\mathrm{HI}\left(-2.20 \mathrm{~kJ} \mathrm{~mol}^{-1}\right)$ are less than the corresponding values in $\operatorname{HOBr}\left(-0.92 \mathrm{~kJ} \mathrm{~mol}^{-1}\right)$ and $\mathrm{HOI}\left(-5.51 \mathrm{~kJ} \mathrm{~mol}^{-1}\right)$, respectively (Figure 1). 


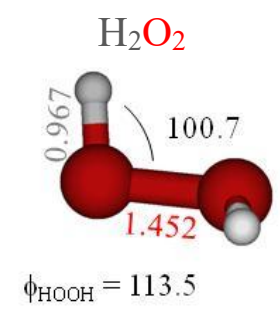

$\mathrm{Br}$

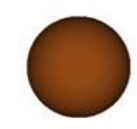

$(-14.00)$

I

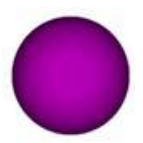

$(-30.54)$
$\mathrm{HO}_{2}$

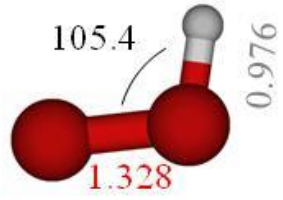

$\mathrm{HBr}$

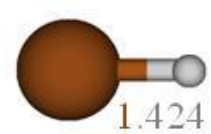

$(-0.61)$

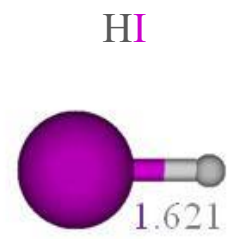

$(-2.20)$
$\mathrm{OH}$

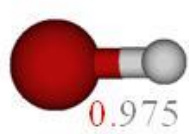

$(-0.83)$

$\mathrm{HOBr}$

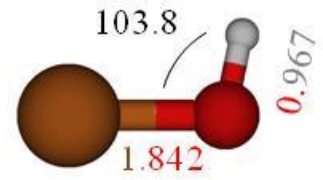

$(-0.92)$

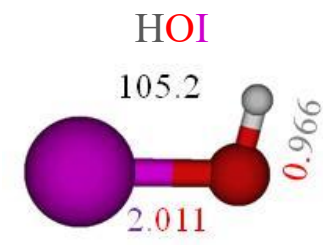

$(-5.51)$

Figure 1. Optimized structures at the B3LYP/aug-cc-pVTZ level of theory for the reactants, and products of the $\mathrm{X}+\mathrm{H}_{2} \mathrm{O}_{2}(\mathrm{X}=\mathrm{Br}, \mathrm{I})$ reactions. Bond lengths and angles are in Angstroms and in degrees, respectively. Spin-Orbit (SO) corrections in $\mathrm{kJ} \mathrm{mol}^{-1}$ calculated at the MRCI/aug-cc-pVTZ level of theory are given in parentheses.. 
Table 2. Rotational Constants, Scaled Vibrational Frequencies ${ }^{\mathrm{a}}$, Scaled Zero-Point Energy (ZPE), and Standard Molar Entropies at $298 \mathrm{~K}$ for Reactants and Products Involved in the X+

$\mathrm{H}_{2} \mathrm{O}_{2}$ Reaction Calculated at the B3LYP/aug-cc-pVTZ Level of Theory.

\begin{tabular}{|l|c|l|l|l|c|c|}
\hline Species & $\begin{array}{c}\text { Symmetry } \\
\text { Number }\end{array}$ & $\begin{array}{c}\text { Electronic } \\
\text { State }\end{array}$ & $\begin{array}{c}\text { Rotational Constants } \\
(\mathrm{GHz})\end{array}$ & \multicolumn{1}{|c|}{$\begin{array}{c}\text { Vibrational Frequencies } \\
\left(\mathrm{cm}^{-1}\right)\end{array}$} & $\begin{array}{c}\mathrm{ZPE} \\
\left(\mathrm{kJ} \mathrm{mol}^{-1}\right)\end{array}$ & $\begin{array}{c}S^{\circ}{ }_{298 \mathrm{~K}} \\
\left(\mathrm{~J} \mathrm{~mol}^{-1} \mathrm{~K}^{-1}\right)\end{array}$ \\
\hline $\mathrm{H}_{2} \mathrm{O}_{2}$ & 2 & $C_{2}-{ }^{1} \mathrm{~A}$ & $25.55,26.40,303.46$ & $362,919,1280,1389,3635,3636$ & 67.1 & 233.22 \\
\hline $\mathrm{HO}_{2}$ & 1 & $C_{s}-{ }^{2} \mathrm{~A}^{\prime \prime}$ & $31.97,33.71,620.54$ & $1121,1386,3473$ & 35.8 & 228.95 \\
\hline $\mathrm{OH}$ & 1 & $C_{{ }_{c}}-{ }^{2} \Pi$ & 560.39 & 3575 & 21.4 & 183.59 \\
\hline $\mathrm{HBr}$ & 1 & $C_{\infty}-{ }^{1} \Sigma$ & 250.34 & 2538 & 15.2 & 198.51 \\
\hline $\mathrm{HI}$ & 1 & $C_{\infty v}-{ }^{1} \Sigma$ & 192.32 & 2219 & 206.57 \\
\hline $\mathrm{HOBr}$ & 1 & $C_{s}-{ }^{1} \mathrm{~A}^{\prime}$ & $10.30,10.47,615.24$ & $619,1147,3655$ & 32.4 & 247.74 \\
\hline $\mathrm{HOI}$ & 1 & $C_{s}-{ }^{1} \mathrm{~A}^{\prime}$ & $8.09,8.20,624.59$ & $562,1057,3668$ & 31.6 & 255.11 \\
\hline
\end{tabular}

${ }^{\mathrm{a}}$ Low-frequency mode treated as hindered rotor is indicated in italics.

Figures 2 and 3 display the optimized geometries of molecular complexes and transition states involved in the respective $\mathrm{Br}+\mathrm{H}_{2} \mathrm{O}_{2}$ and $\mathrm{I}+\mathrm{H}_{2} \mathrm{O}_{2}$ reactions while Table 4 provides the corresponding wavenumbers and ZPE values. 

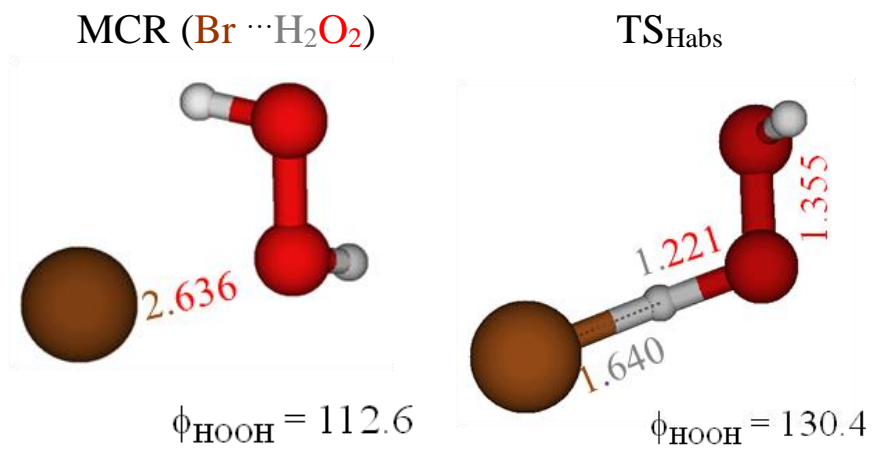

$$
\mathrm{MCP}_{\text {Habs }}\left(\mathrm{HBr}^{\cdots} \mathrm{HO}_{2}\right)
$$

TS $\mathrm{OHabs}$
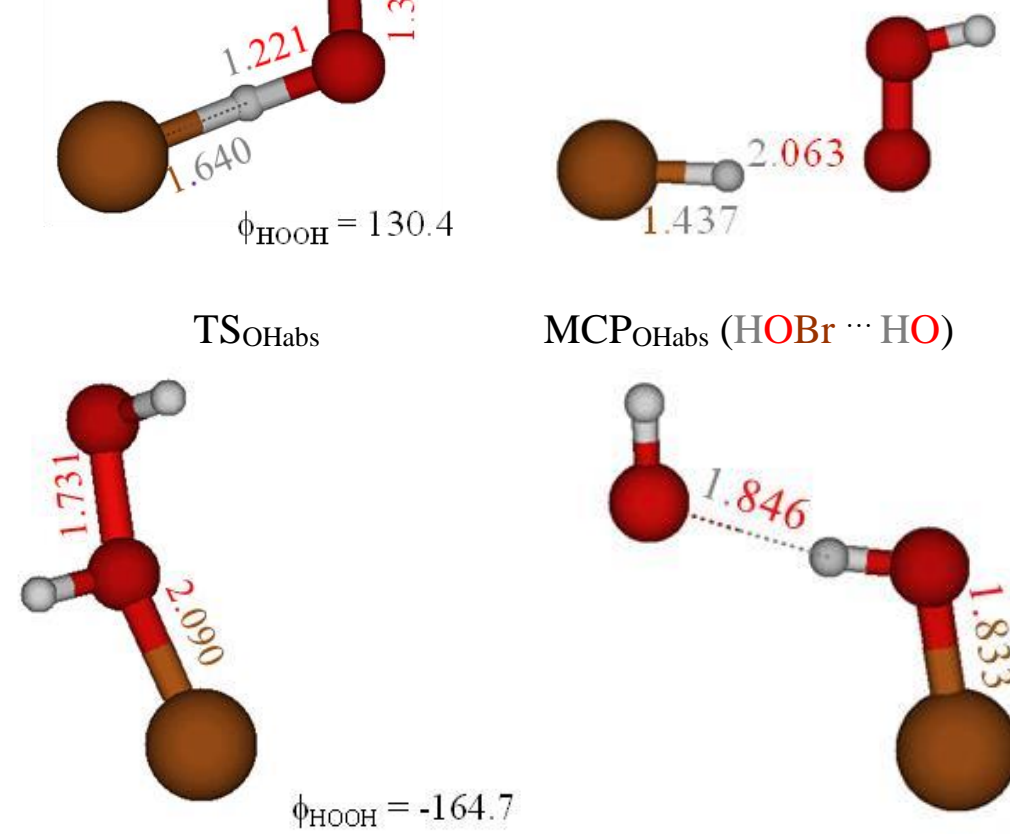

MCP ${ }_{\text {OHabs }}(\mathrm{HOBr} \cdots \mathrm{HO})$

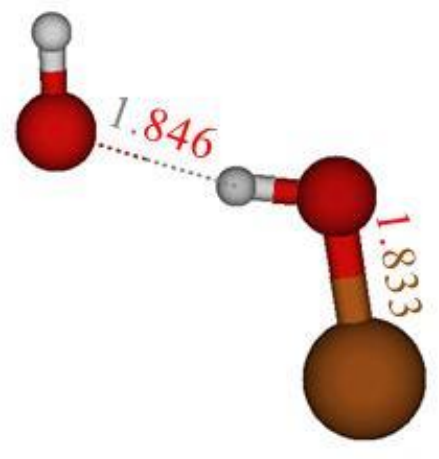

Figure 2. Structures optimized at the B3LYP/aug-cc-pVTZ level of theory for the molecular complexes, and transition states of the $\mathrm{Br}+\mathrm{H}_{2} \mathrm{O}_{2}$ reaction. Bond lengths and dihedral angles are in Angstroms and in degrees, respectively. 


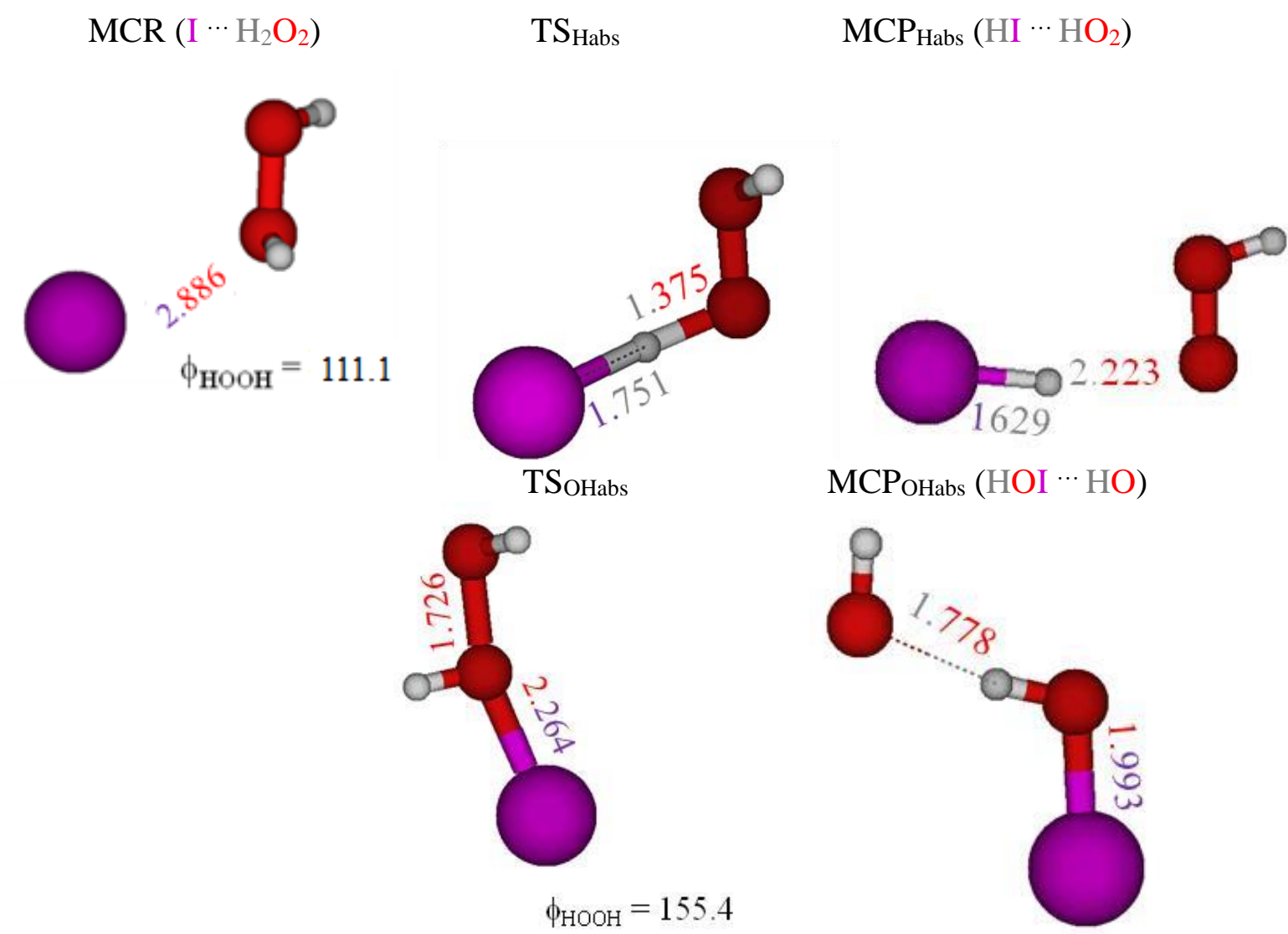

Figure 3. Structures optimized at the B3LYP/aug-cc-pVTZ level of theory for the molecular complexes, and transition states for the $\mathrm{I}+\mathrm{H}_{2} \mathrm{O}_{2}$ reaction. Bond lengths and dihedral angles are in Angstroms and degrees, respectively.

\section{Transition States}

The emerging $\mathrm{H}-\mathrm{X}$ bond lengths in $\mathrm{TS}_{\mathrm{Habs}}(1.64$ and $1.75 \AA$ for $\mathrm{H}-\mathrm{Br}$ and $\mathrm{H}-\mathrm{I}$, respectively) are elongated with respect to the corresponding HX products (1.42 and $1.62 \AA$ for the respective $\mathrm{HBr}$ and $\mathrm{HI})$. The breaking $\mathrm{O}-\mathrm{H}$ bond is longer in $\mathrm{TS}_{\mathrm{Habs} / \mathrm{I}+\mathrm{H} 2 \mathrm{O} 2}(1.37 \AA)$ than in $\mathrm{TS}_{\mathrm{Habs} / \mathrm{Br}+\mathrm{H} 2 \mathrm{O} 2}$

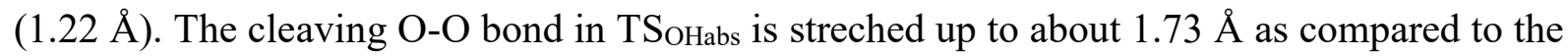
OO bond distance in $\mathrm{H}_{2} \mathrm{O}_{2}$ reactant (1.45 $\AA$ ). Similarly, the nascent $\mathrm{X}-\mathrm{O}(\mathrm{H})$ bonds $(2.09$ and $2.26 \AA$ for $\mathrm{Br}-\mathrm{OH}$ and $\mathrm{I}-\mathrm{OH}$, respectively) are longer in TS $\mathrm{OHabs}_{\text {s }}$ than in the corresponding HOX products (1.84 and 2.01 $\AA$ for HO-Br and HO-I, respectively). The SOC of TS $\mathrm{S}_{\mathrm{Habs} / \mathrm{I}+\mathrm{H} 2 \mathrm{O} 2}(-3.08$ $\left.\mathrm{kJ} \mathrm{mol}^{-1}\right)$ is product-like as it tends towards the SOC value of $\mathrm{HI}\left(-2.20 \mathrm{~kJ} \mathrm{~mol}^{-1}\right)$.

\section{Molecular Complexes}


$\mathrm{Br}$ and $\mathrm{I}$ atoms interact through halogen bonds within the prereactive complexes whereas hydrogen interactions between $\mathrm{HX}$ and $\mathrm{HOX}$ with $\mathrm{HO}_{2}$ and $\mathrm{OH}$ can be found inside $\mathrm{MCP}_{\text {Habs }}$ and $\mathrm{MCP}_{\mathrm{OHabs}}$, respectively. In MCR, the $\mathrm{Br} \cdots \mathrm{O}$ interaction $(2.64 \AA)$ is shorter than the $\mathrm{I} \cdots \mathrm{O}$ intermolecular distance (2.89 $\AA$ ). As to MCP, hydrogen interactions between $\mathrm{OH}$ and $\mathrm{HOX}$ (1.90 $\AA$ ) are slightly stronger than the $\mathrm{H}_{\mathrm{HX}} \cdots \mathrm{O}_{\mathrm{HO}}$ hydrogen bonds $(\sim 2.00 \AA)$. It can be noted that the SOC of Br and I (-14.0 and $\left.-30.54 \mathrm{~kJ} \mathrm{~mol}^{-1}\right)$ are quenched down to -4.43 and $-18.78 \mathrm{~kJ}$ $\mathrm{mol}^{-1}$, respectively within the MCR the atoms undergo halogen bonds. 
Table 4. Rotational Constants, Scaled Vibrational Frequencies ${ }^{\mathrm{a}}$, Scaled Zero-Point Energy (ZPE), and Spin-Orbit Coupling ${ }^{\mathrm{b}}$ (SOC) for Intermediate Species Involved in the $\mathrm{X}+\mathrm{H}_{2} \mathrm{O}_{2}$ Reaction Calculated at the B3LYP/aug-cc-pVTZ Level of Theory.

\begin{tabular}{|c|c|c|c|c|c|c|}
\hline Species & $\begin{array}{l}\text { Symmetry } \\
\text { Number }\end{array}$ & $\begin{array}{l}\text { Electronic } \\
\text { State }\end{array}$ & $\begin{array}{c}\text { Rotational Constants } \\
(\mathrm{GHz})\end{array}$ & $\begin{array}{c}\text { Vibrational Frequencies } \\
\left(\mathrm{cm}^{-1}\right)\end{array}$ & $\begin{array}{c}\mathrm{ZPE} \\
\mathrm{kJ} \mathrm{mol}^{-1}\end{array}$ & $\begin{array}{c}\mathrm{SOC} \\
\mathrm{kJ} \mathrm{mol}^{-1}\end{array}$ \\
\hline \multicolumn{7}{|c|}{$\mathrm{Br}+\mathrm{H}_{2} \mathrm{O}_{2}=$ products } \\
\hline MCR & 1 & $C_{l}-{ }^{2} \mathrm{~A}$ & $2.33,2.49,32.11$ & $90,174,207,406,913,1282,1396,3575,3590$ & 69.6 & -4.43 \\
\hline $\mathrm{TS}_{\mathrm{Habs}}$ & 1 & $C_{l}-{ }^{2} \mathrm{~A}$ & $2.07,2.16,43.89$ & $\mathbf{1 3 8 7 i}, 144,299,356,844,1050,1072,1393,3538$ & 52.0 & -0.94 \\
\hline $\mathrm{MCP}_{\text {Habs }}$ & 1 & $C_{l}-{ }^{2} \mathrm{~A}$ & $1.44,1.49,45.22$ & $46,105,147,367,377,1132,1391,2397,3478$ & 56.5 & -0.01 \\
\hline $\mathrm{TS}_{\mathrm{OHabs}}$ & 1 & $C_{l}-{ }^{2} \mathrm{~A}$ & $2.31,2.34,83.16$ & $\mathbf{6 3 2 i}, 165,230,356,446,962,1110,3636,3641$ & 63.1 & -1.55 \\
\hline $\mathrm{MCP}_{\mathrm{OHabs}}$ & 1 & $C_{l}-{ }^{2} \mathrm{~A}$ & $2.05,2.24,25.27$ & $59,103,138,266,323,626,1249,3404,3565$ & 58.2 & -0.88 \\
\hline \multicolumn{7}{|c|}{$\mathrm{I}+\mathrm{H}_{2} \mathrm{O}_{2}=$ products } \\
\hline MCR & 1 & $C_{l}-{ }^{2} \mathrm{~A}$ & $1.78,1.87,31.75$ & $75,131,207,390,915,1288,1391,3576,3603$ & 69.2 & -18.78 \\
\hline $\mathrm{TS}_{\text {Habs }}$ & 1 & $C_{l}-{ }^{2} \mathrm{~A}$ & $1.58,1.63,43.39$ & $\mathbf{1 0 0 5 i}, 126,301,317,712,811,1093,1382,3521$ & 49.4 & -3.08 \\
\hline $\mathrm{MCP}_{\text {Habs }}$ & 1 & $C_{l}-{ }^{2} \mathrm{~A}$ & $1.09,1.12,44.19$ & $35,81,113,276,279,1129,1388,2142,3477$ & 53.4 & -2.23 \\
\hline TS OHabs & 1 & $C_{l}-{ }^{2} \mathrm{~A}$ & $1.86,1.88,82.11$ & 617i, 142, 204, 312, 403, 962, 1096, 3642, 3645 & 62.2 & -8.50 \\
\hline $\mathrm{MCP}_{\mathrm{OHabs}}$ & 1 & $C_{l}-{ }^{2} \mathrm{~A}$ & $1.77,1.91,23.85$ & $34,79,138,216,341,582,1189,3287,3576$ & 56.5 & -4.82 \\
\hline
\end{tabular}

${ }^{\text {a }}$ Low-frequency mode treated as hindered rotor is indicated in italics. ${ }^{\mathrm{b}}$ SOC calculations at the MRCI/aug-cc-pVTZ Level of Theory. 


\section{Energetics}

The enthalpies at $0 \mathrm{~K}\left(\Delta H_{0 K}\right)$ of the stationary points relative to $\mathrm{X}+\mathrm{H}_{2} \mathrm{O}_{2}(\mathrm{X}=\mathrm{Br}, \mathrm{I})$ are collected in Table 5. The reaction enthalpies at 0 and $298 \mathrm{~K}\left(\Delta_{\mathrm{r}} H_{0 \mathrm{~K}}\right.$ and $\left.\Delta_{\mathrm{r}} H^{\circ}{ }_{298 \mathrm{~K}}\right)$ and the standard Gibbs free reaction energies $\Delta_{\mathrm{r}} G^{\circ}{ }_{298 \mathrm{~K}}$ for the $\mathrm{H}$ - and $\mathrm{OH}$-abstraction pathways for each reaction have been also calculated including different corrections and given in Table 6 .

Table 5. Various Energy Contributions to the Enthalpies at $0 \mathrm{~K}$ for the Intermediate Species Relative to $\mathrm{X}+\mathrm{H}_{2} \mathrm{O}_{2}\left(\mathrm{X}=\mathrm{Br}\right.$, I) Reactions (in $\mathrm{kJ} \mathrm{mol}^{-1}$ ).

\begin{tabular}{|l|c|c|c|c|c|c|}
\hline Species & $\Delta E_{C B S}$ & $\Delta E_{\mathrm{ZPE}}$ & $\Delta E_{\mathrm{CV}}$ & $\Delta E_{\mathrm{SR}}$ & $\Delta E_{\mathrm{SO}}$ & $\Delta H_{0 \mathrm{~K}}$ \\
\hline \multicolumn{7}{|c|}{$\mathrm{Br}+\mathrm{H}_{2} \mathrm{O}_{2}=$ products } \\
\hline $\mathrm{MCR}$ & -15.0 & 2.5 & -0.8 & -0.3 & 9.6 & -4.0 \\
\hline $\mathrm{TS}_{\text {Habs }}$ & 45.5 & -15.1 & 2.0 & 1.4 & 13.1 & 42.9 \\
\hline $\mathrm{MCP}_{\text {Habs }}$ & -12.7 & -10.6 & -2.1 & 2.2 & 14.0 & -9.2 \\
\hline $\mathrm{TS}_{\text {OHabs }}$ & 50.8 & -4.0 & 0.0 & -0.6 & 12.5 & 58.6 \\
\hline $\mathrm{MCP}_{\text {OHabs }}$ & -25.2 & -8.9 & -0.8 & 2.3 & 13.1 & -19.5 \\
\hline & & $\mathrm{I}+\mathrm{H}_{2} \mathrm{O}_{2}=$ products & & \\
\hline $\mathrm{MCR}$ & -13.2 & 2.1 & -0.9 & 0.0 & 11.8 & -0.2 \\
\hline $\mathrm{TS}_{\text {Habs }}$ & 86.8 & -17.7 & -3.8 & -0.6 & 27.5 & 92.2 \\
\hline $\mathrm{MCP}_{\text {Habs }}$ & 50.0 & -13.8 & -3.8 & -0.5 & 28.3 & 60.3 \\
\hline TS $_{\text {OHabs }}$ & 50.1 & -4.9 & -0.3 & -0.7 & 22.0 & 66.4 \\
\hline $\mathrm{MCP}_{\text {OHabs }}$ & -25.0 & -10.6 & -0.5 & 0.0 & 25.7 & -10.4 \\
\hline
\end{tabular}

Table 6. Reaction Enthalpies at 0 and $298 \mathrm{~K}\left(\Delta_{\mathrm{r}} H_{0 \mathrm{~K}}\right.$ and $\left.\Delta_{\mathrm{r}} H^{\circ}{ }_{298 \mathrm{~K}}\right)$ and the Standard Gibbs Free Reaction Energies $\Delta_{\mathrm{r}} G^{\circ}{ }_{298 \mathrm{~K}}$, Calculated in $\mathrm{kJ} \mathrm{mol}^{-1}$ on B3LYP Geometries at the $\operatorname{CCSD}(\mathrm{T}) / \mathrm{CBS}(\mathrm{T}, \mathrm{Q})$ Level of Theory.

\begin{tabular}{|l|c|c|c|c|c|c|}
\hline \multirow{2}{*}{ Reaction Channels } & \multicolumn{3}{|c|}{$\mathrm{X}=\mathrm{Br}$} & \multicolumn{3}{c|}{$\mathrm{X}=\mathrm{I}$} \\
\cline { 2 - 7 } & $\Delta_{\mathrm{r}} H_{0 \mathrm{~K}}$ & $\Delta_{\mathrm{r}} H^{\circ}{ }_{298 \mathrm{~K}}$ & $\Delta_{\mathrm{r}} G^{\circ}{ }_{298 \mathrm{~K}}$ & $\Delta_{\mathrm{r}} H^{\circ}{ }_{0 \mathrm{~K}}$ & $\Delta_{\mathrm{r}} H^{\circ}{ }_{298 \mathrm{~K}}$ & $\Delta_{\mathrm{r}} G^{\circ}{ }_{298 \mathrm{~K}}$ \\
\hline $\mathrm{X}+\mathrm{H}_{2} \mathrm{O}_{2} \rightarrow \mathrm{HX}+\mathrm{HO}_{2}$ & -1.6 & -0.2 & -6.0 & 66.2 & 67.7 & 61.2 \\
\hline $\mathrm{X}+\mathrm{H}_{2} \mathrm{O}_{2} \rightarrow \mathrm{HOX}+\mathrm{OH}$ & -5.6 & -3.2 & -10.1 & 2.0 & 4.5 & -2.9 \\
\hline
\end{tabular}


According to our predicted results, the $\mathrm{H}$ - and $\mathrm{O}(\mathrm{H})$ - abstraction channels of the $\mathrm{Br}+\mathrm{H}_{2} \mathrm{O}_{2}$ reaction are exothermic. The most favored pathway corresponds to the formation of $(\mathrm{HBr}+$ $\mathrm{HO}_{2}$ ). As regards with the $\mathrm{I}+\mathrm{H}_{2} \mathrm{O}_{2}$ reaction, our values reveal that the $\mathrm{H}$ - and $\mathrm{OH}$-abstraction pathways are endothermic. The calculated reaction enthalpy at $298 \mathrm{~K}$ for the $\mathrm{H}$-abstraction channel (-0.2 $\mathrm{kJ} \mathrm{mol}^{-1}$ and $67.7 \mathrm{~kJ} \mathrm{~mol}^{-1}$ for $\mathrm{Br}+\mathrm{H}_{2} \mathrm{O}_{2}$ and $\mathrm{I}+\mathrm{H}_{2} \mathrm{O}_{2}$ reactions respectively) are in excellent agreement with the available literature data ${ }^{56}\left(-0.3 \mathrm{~kJ} \mathrm{~mol}^{-1}\right.$ and $67.6 \mathrm{~kJ} \mathrm{~mol}^{-1}$, respectively), whereas for the $\mathrm{OH}$-abstraction channel obtained values $\left(-3.2 \mathrm{~kJ} \mathrm{~mol}^{-1}\right.$ and $4.5 \mathrm{~kJ}$ $\mathrm{mol}^{-1}$ for $\mathrm{Br}+\mathrm{H}_{2} \mathrm{O}_{2}$ and $\mathrm{I}+\mathrm{H}_{2} \mathrm{O}_{2}$ reactions respectively) are not satisfactory compared to the literature $^{56}\left(1.0 \mathrm{~kJ} \mathrm{~mol}^{-1}\right.$ and $4.5 \mathrm{~kJ} \mathrm{~mol}^{-1}$, respectively). This difference can result from the value of the standard enthalpy of formation of $\operatorname{HOX}(\mathrm{X}=\mathrm{Br}, \mathrm{I})$ since the heat of formation of these species is still an open problem.

In order to provide a new estimation of the standard enthalpy of formation at $298 \mathrm{~K}$ of $\mathrm{HOBr}$ and $\mathrm{HOI}$, the following reactions $(\mathrm{X}=\mathrm{Br}, \mathrm{I})$ have been used as in our previous work ${ }^{54}$ :

$$
\begin{aligned}
& \mathrm{X}+\mathrm{OH}=\mathrm{HOX} \\
& \mathrm{HX}+\mathrm{HOX}=\mathrm{X}_{2}+\mathrm{H}_{2} \mathrm{O} \\
& \mathrm{XO}+\mathrm{H}=\mathrm{HOX} \\
& \mathrm{XO}+\mathrm{HX}=\mathrm{X}+\mathrm{HOX} \\
& \mathrm{X}_{2}+\mathrm{OH}=\mathrm{X}+\mathrm{HOX} \\
& \mathrm{HOX}+\mathrm{H}=\mathrm{XO}+\mathrm{H}_{2} \\
& \mathrm{HOX}+\mathrm{O}=\mathrm{XO}+\mathrm{OH}^{\mathrm{HOX}}+\mathrm{OH}=\mathrm{XO}+\mathrm{H}_{2} \mathrm{O}
\end{aligned}
$$


The studied reactions contain both atomization and isogyric reactions (b, d, e, f, and h). To derive the $\Delta_{\mathrm{f}} H^{\circ}{ }_{298 \mathrm{~K}}$ of $\mathrm{HOX}$, the literature data taken from the last evaluation of the $\mathrm{JPL}^{56}$ have been used and their values are listed in Table 7. The obtained values of the standard enthalpy of formation of $\mathrm{HOBr}$ and $\mathrm{HOI}$ at $298 \mathrm{~K}$ are given in Table 8.

Table 7. Literature Standard Enthalpies of Formation at $298 \mathrm{~K}$.

\begin{tabular}{lc}
\hline Species & $\begin{array}{c}\Delta_{\mathrm{f}} \mathrm{H}^{\circ}{ }_{298 \mathrm{~K}} \\
\left(\mathrm{~kJ} \mathrm{~mol}{ }^{-1}\right)\end{array}$ \\
\hline $\mathrm{H}$ & $217.997 \pm 0.0001$ \\
$\mathrm{O}$ & $249.229 \pm 0.002$ \\
$\mathrm{Br}$ & $111.87 \pm 0.12$ \\
$\mathrm{I}$ & $106.76 \pm 0.04$ \\
$\mathrm{Br}_{2}$ & $30.91 \pm 0.11$ \\
$\mathrm{I}_{2}$ & $62.42 \pm 0.08$ \\
$\mathrm{OH}$ & $37.492 \pm 0.026$ \\
$\mathrm{HI}$ & $26.5 \pm 0.1$ \\
$\mathrm{HBr}$ & $-36.29 \pm 0.16$ \\
$\mathrm{BrO}$ & $123.4 \pm 0.4$ \\
$\mathrm{IO}$ & $122.2 \pm 1.3$ \\
$\mathrm{H} 2 \mathrm{O}$ & $-241.831 \pm 0.026$ \\
\hline
\end{tabular}

Table 8. Standard Enthalpies of Formation ${ }^{\mathrm{a}}$ at $\left.298 \mathrm{~K}_{(\mathrm{kJ} \mathrm{mol}}{ }^{-1}\right)$ of $\mathrm{HOBr}$ and HOI Obtained from the Selected Reactions.

\begin{tabular}{|l|l|c|c|c|c|c|}
\hline \multirow{2}{*}{ Reaction } & \multicolumn{2}{|c|}{$\mathrm{X}=\mathrm{Br}$} & \multicolumn{3}{c|}{$\mathrm{X}=\mathrm{I}$} & \\
\cline { 3 - 7 } & Atomization & $\Delta_{\mathrm{f}} H^{\circ}{ }_{298 \mathrm{~K}}$ & $\Delta \Delta_{\mathrm{f}} H^{\circ}{ }_{298 \mathrm{~K}}$ & \multicolumn{1}{c|}{$\Delta_{\mathrm{f}} H^{\circ}{ }_{298 \mathrm{~K}}$} & $\Delta \Delta_{\mathrm{f}} H^{\circ}{ }_{298 \mathrm{~K}}$ & Type \\
\hline (a) & $\mathrm{X}+\mathrm{OH}=\mathrm{HOX}$ & -56.1 & 0.12 & -65.2 & 0.04 & \\
\hline (b) & $\mathrm{HX}+\mathrm{HOX}=\mathrm{X}_{2}+\mathrm{H}_{2} \mathrm{O}$ & -63.5 & 0.07 & -60.6 & 0.07 & \\
\hline (c) & $\mathrm{XO}+\mathrm{H}=\mathrm{HOX}$ & -71.1 & 0.10 & -71.4 & 1.30 & \\
\hline (d) & $\mathrm{XO}+\mathrm{HX}=\mathrm{X}+\mathrm{HOX}$ & -69.9 & 1.44 & -70.5 & 1.44 & Isogyric \\
\hline (e) & $\mathrm{X}_{2}+\mathrm{OH}=\mathrm{X}+\mathrm{HOX}$ & -61.9 & 0.15 & -62.3 & 0.15 & Isogyric \\
\hline (f) & $\mathrm{HOX}+\mathrm{H}=\mathrm{XO}+\mathrm{H}_{2}$ & -70.1 & 1.30 & -70.7 & 1.30 & Isogyric \\
\hline (g) & $\mathrm{HOX}+\mathrm{O}=\mathrm{XO}+\mathrm{OH}$ & -68.6 & 1.33 & -69.8 & 1.33 & \\
\hline (h) & $\mathrm{HOX}+\mathrm{OH}=\mathrm{XO}+\mathrm{H}_{2} \mathrm{O}$ & -68.6 & 1.35 & -69.3 & 1.35 & Isogyric \\
\hline
\end{tabular}

a The associated uncertainties $\left(\Delta \Delta_{\mathrm{f}} H^{\circ}{ }_{298 \mathrm{~K}}\right)$ are equivalent to the sum of uncertainties for all involved species. 
The $\Delta_{\mathrm{f}} H^{\circ}{ }_{298 \mathrm{~K}}(\mathrm{HOBr})$ derived from the atomization reaction $(-56.1 \pm 0.12) \mathrm{kJ} \mathrm{mol}^{-1}$ is in a very good agreement with the widely used experimental value of the standard enthalpy of formation of $\mathrm{HOBr}$ at $298 \mathrm{~K}$ of Ruscic and Berkowitz ${ }^{57}$ obtained from the photoionization onset for fragmentation into $\mathrm{Br}^{+}$and $\mathrm{OH}\left[(-56.2 \pm 1.8) \mathrm{kJ} \mathrm{mol}^{-1}\right]$. The present value is $4.4 \mathrm{~kJ} \mathrm{~mol}^{-1}$ lower than the $\operatorname{CCSD}(\mathrm{T})$ calculated value given by Hassanzadeh et al. ${ }^{58}\left[(-60.5 \pm 1.1) \mathrm{kJ}^{\mathrm{mol}}{ }^{-}\right.$ $\left.{ }^{1}\right)$ ] and it is lower than the more recent measurement of Lock et al. ${ }^{59}\left[(-61.92 \pm 4.2) \mathrm{kJ} \mathrm{mol}^{-1}\right]$. Considering only the isogyric reactions (b, d, e, f, and h) our calculated value is $-66.2 \mathrm{~kJ} \mathrm{~mol}^{-1}$ associated to a standard deviation of $4.6 \mathrm{~kJ} \mathrm{~mol}^{-1}$. Extending the set to all reactions $(\mathrm{a}, \mathrm{b}, \mathrm{c}, \mathrm{d}$, $\mathrm{e}, \mathrm{f}, \mathrm{g}$, and $\mathrm{h})$, the following value is obtained: $\Delta_{\mathrm{f}} \mathrm{H}^{\circ}{ }_{298 \mathrm{~K}}=(-66.8 \pm 4.2) \mathrm{kJ} \mathrm{mol}^{-1}$ whose value is closer to the CCSD(T) calculated value of Denis ${ }^{60}\left[(-64.01 \pm 2.51) \mathrm{kJ} \mathrm{mol}^{-1}\right]$.

The atomization process is used to derive the $\Delta_{\mathrm{f}} H^{\circ}{ }_{298 \mathrm{~K}}$ of $\mathrm{HOI}$, obtained value is $(-65.2 \pm$ $0.04) \mathrm{kJ} \mathrm{mol}^{-1}$. The calculated value from all studied reactions $(\mathrm{a}-\mathrm{h})$ is $: \Delta_{\mathrm{f}} H^{\circ}{ }_{298 \mathrm{~K}}=(-67.0 \pm 4.8)$ $\mathrm{kJ} \mathrm{mol}^{-1}$ is similar to the calculated one restricting just the isogyric set (b, d, e, f, and h) $\Delta_{\mathrm{f}} H^{\circ}{ }_{298 \mathrm{~K}}$ $=(-66.8 \pm 4.7) \mathrm{kJ} \mathrm{mol}^{-1}$. Our new estimated value is in a good agreement with the values proposed by Sulkovà et al. ${ }^{54} \Delta_{\mathrm{f}} H^{\circ}{ }_{298 \mathrm{~K}}=(-69.0 \pm 3.7) \mathrm{kJ} \mathrm{mol}^{-1}$ using the CR-CCSD(T)/ANORCC-large level of theory and the one obtained by Berry et al. $^{61}\left[(-69.6 \pm 5.4) \mathrm{kJ} \mathrm{mol}^{-1}\right]$ derived from activation energy using the flash photolysis-resonance fluorescence technique.

Our updated $\Delta_{\mathrm{f}} H^{\circ}{ }_{298 \mathrm{~K}}$ values for $\mathrm{HOBr}$ and $\mathrm{HOI}$ derived from the set of isogyric reactions are $\Delta_{\mathrm{f}} H^{\circ}{ }_{298 \mathrm{~K}}(\mathrm{HOBr})=(-66.2 \pm 4.6) \mathrm{kJ} \mathrm{mol}^{-1}$ and $\Delta_{\mathrm{f}} H^{\circ}{ }_{298 \mathrm{~K}}(\mathrm{HOI})=(-66.8 \pm 4.7) \mathrm{kJ} \mathrm{mol}^{-1}$. In the case of $\mathrm{HOBr}$, there is a significant change in its value by comparison to the one proposed $(-60.5 \pm 1.1) \mathrm{kJ} \mathrm{mol}^{-1}$ in the last JPL evaluation number issued in 2015. ${ }^{56}$ 
The standard Gibbs free reaction energies $\Delta_{\mathrm{r}} G^{\circ}{ }_{298 \mathrm{~K}}$ have been calculated and used in the rate constants calculation. The resulting values of $\Delta_{\mathrm{r}} G^{\circ} 298 \mathrm{~K}$ are $-6.0 \mathrm{~kJ} \mathrm{~mol}^{-1}$ for $\mathrm{H}$-abstraction and $-10.1 \mathrm{~kJ} \mathrm{~mol}^{-1}$ for $\mathrm{OH}$-abstraction for the $\mathrm{Br}+\mathrm{H}_{2} \mathrm{O}_{2}$ reaction and $+61.2 \mathrm{~kJ} \mathrm{~mol}^{-1}$ for $\mathrm{H}-$ abstraction and $-2.9 \mathrm{~kJ} \mathrm{~mol}^{-1}$ for $\mathrm{OH}-\mathrm{abstraction}$ for the $\mathrm{I}+\mathrm{H}_{2} \mathrm{O}_{2}$ reaction. Our results showed that for $\mathrm{Br}+\mathrm{H}_{2} \mathrm{O}_{2}$ reaction the two studied channels are spontaneous at $298 \mathrm{~K}$ and 1 bar while for the $\mathrm{I}+\mathrm{H}_{2} \mathrm{O}_{2}$ reaction only the $\mathrm{OH}$-abstraction channel is spontaneous at $298 \mathrm{~K}$ and 1 bar.

The reaction profiles relative to $\mathrm{Br}+\mathrm{H}_{2} \mathrm{O}_{2}$ and $\mathrm{I}+\mathrm{H}_{2} \mathrm{O}_{2}$ at $0 \mathrm{~K}$ are shown in Figures 4 and 5 respectively, at the $\operatorname{CCSD}(\mathrm{T}) / \mathrm{CBS}(\mathrm{T}, \mathrm{Q})$ level of theory including ZPE, CV, SO, and SR corrections on B3LYP/aug-cc-pVTZ geometries. According to the reaction profiles, the formation of the same prereactive complex MCR is observed for the $\mathrm{H}$ - and $\mathrm{OH}$-abstraction pathways at $4.0 \mathrm{~kJ} \mathrm{~mol}^{-1}$ and $0.2 \mathrm{~kJ} \mathrm{~mol}^{-1}$ below reactants for $\mathrm{Br}+\mathrm{H}_{2} \mathrm{O}_{2}$ and $\mathrm{I}+\mathrm{H}_{2} \mathrm{O}_{2}$ reactions, respectively. The reactants have to overcome a barrier of $42.9 \mathrm{~kJ} \mathrm{~mol}^{-1}$ and $58.6 \mathrm{~kJ} \mathrm{~mol}^{-1}(66.4$ $\mathrm{kJ} \mathrm{mol}^{-1}$ and $\left.92.2 \mathrm{~kJ} \mathrm{~mol}^{-1}\right)$ that correspond to the $\mathrm{H}$ - and $\mathrm{OH}$-abstraction for $\mathrm{Br}+\mathrm{H}_{2} \mathrm{O}_{2}(\mathrm{I}+$ $\mathrm{H}_{2} \mathrm{O}_{2}$ ). The existing of such barriers is hindering the direct formation of products without providing additional energy to the systems. The formed $\mathrm{MCP}_{\text {Habs }}$ and $\mathrm{MCP}_{\text {OHabs }}$ of the $\mathrm{Br}+$ $\mathrm{H}_{2} \mathrm{O}_{2}$ are stable, they are located about 9 and $19 \mathrm{~kJ} \mathrm{~mol}^{-1}$ below reactants, respectively. Whereas for the $\mathrm{I}+\mathrm{H}_{2} \mathrm{O}_{2}$ reaction, only the $\mathrm{MCP}_{\text {Habs }}$ is stable (located about $10 \mathrm{~kJ} \mathrm{~mol}^{-1}$ below reactants), the $\mathrm{MCP}_{\mathrm{OHabs}}$ is not stable and it is located about $60 \mathrm{~kJ} \mathrm{~mol}^{-1}$ above reactants. 


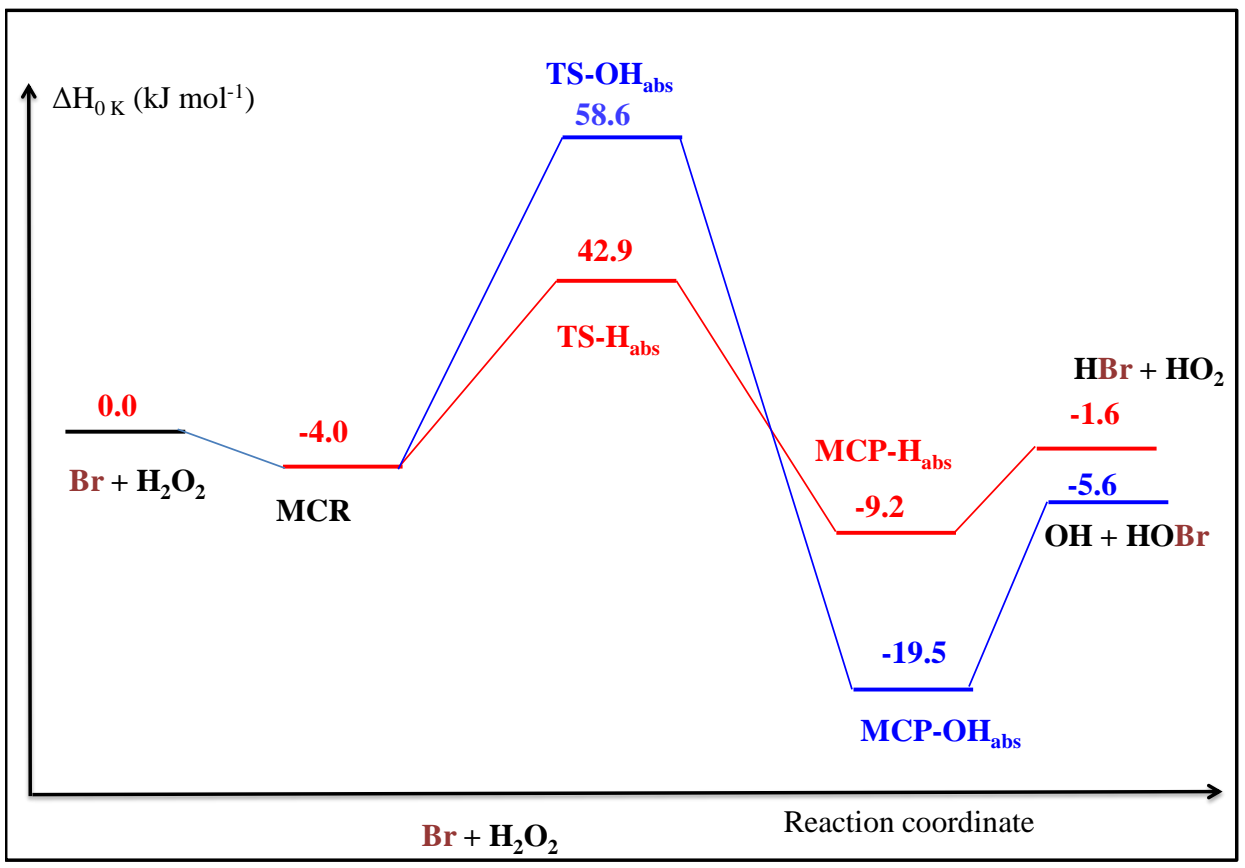

Figure 5. Reaction profile relative to $\mathrm{Br}+\mathrm{H}_{2} \mathrm{O}_{2}$ at $0 \mathrm{~K}$ calculated at the $\mathrm{CCSD}(\mathrm{T}) / \mathrm{CBS}(\mathrm{T}, \mathrm{Q})$ levels of theory on geometries obtained using the B3LYP/aug-cc-pVTZ method.

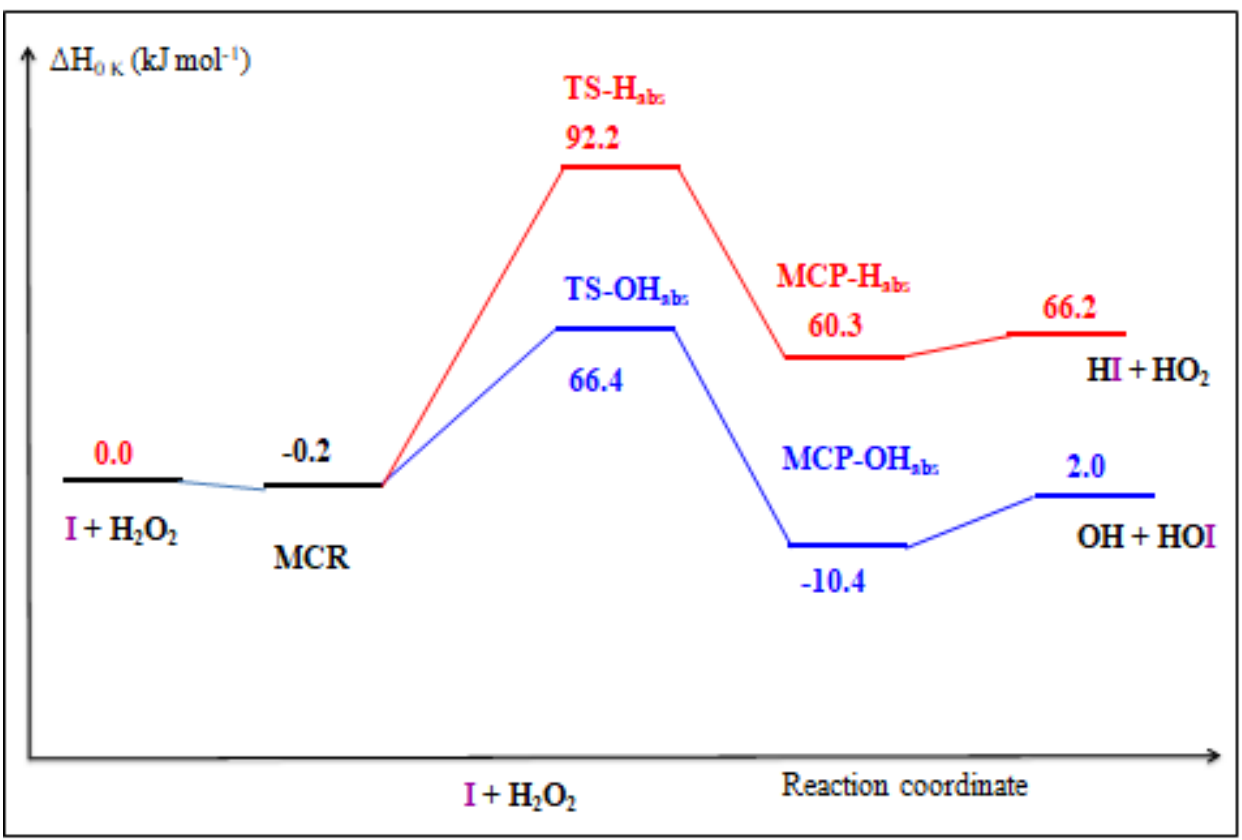

Figure 6. Reaction profile relative to $\mathrm{I}+\mathrm{H}_{2} \mathrm{O}_{2}$ at $0 \mathrm{~K}$ calculated at the $\mathrm{CCSD}(\mathrm{T}) / \mathrm{CBS}(\mathrm{T}, \mathrm{Q})$ levels of theory on geometries obtained using the B3LYP/aug-cc-pVTZ method. 


\section{Rate constants}

As noted above, the $\operatorname{CCSD}(\mathrm{T}) / \mathrm{CBS}$ level of theory including $\mathrm{ZPE}, \mathrm{CV}$, SO, and SR corrections has been used to determine the rate constants associated with the $\mathrm{H}-$ and $\mathrm{OH}$ abstraction pathways over $250-2500 \mathrm{~K}$. The calculated rate constants for both reaction pathways and also the overall reaction rate are plotted against 1000/T in Figures 7 and 8 for the $\mathrm{Br}+\mathrm{H}_{2} \mathrm{O}_{2}$ and $\mathrm{I}+\mathrm{H}_{2} \mathrm{O}_{2}$ reactions, respectively. Calculated values are given in Table 9 at different temperatures $(250,300,500,1000,1500$, and $2500 \mathrm{~K})$ including the hindered rotor corrections.

Table 9. Rate Constants Evaluated at the CCSD(T)/CBS(T,Q)//B3LYP/aug-cc-pVTZ Level of Theory $\left(\mathrm{cm}^{3}\right.$ molecule $\left.{ }^{-1} \mathrm{~s}^{-1}\right)$ Including the Hindered Rotor Corrections.

\begin{tabular}{|l|c|c|c|c|c|c|}
\hline $\mathrm{T}(\mathrm{K})$ & 250 & 300 & 500 & 1000 & 1500 & 2500 \\
\hline \multicolumn{7}{|c|}{$\mathrm{Br}+\mathrm{H}_{2} \mathrm{O}_{2}$} \\
\hline H-abstraction & $1.55 \times 10^{-19}$ & $1.53 \times 10^{-18}$ & $5.64 \times 10^{-16}$ & $1.94 \times 10^{-13}$ & $2.32 \times 10^{-12}$ & $2.57 \times 10^{-11}$ \\
\hline OH-abstraction & $1.84 \times 10^{-24}$ & $1.94 \times 10^{-22}$ & $3.47 \times 10^{-18}$ & $1.30 \times 10^{-14}$ & $3.09 \times 10^{-13}$ & $5.58 \times 10^{-12}$ \\
\hline Overall & $1.55 \times 10^{-19}$ & $1.53 \times 10^{-18}$ & $5.67 \times 10^{-16}$ & $2.07 \times 10^{-13}$ & $2.63 \times 10^{-12}$ & $3.13 \times 10^{-11}$ \\
\hline \multicolumn{7}{|c|}{$\mathrm{I}+\mathrm{H}_{2} \mathrm{O}_{2}$} \\
\hline H-abstraction & $1.63 \times 10^{-30}$ & $1.81 \times 10^{-27}$ & $4.62 \times 10^{-21}$ & $9.16 \times 10^{-16}$ & $8.95 \times 10^{-14}$ & $5.39 \times 10^{-12}$ \\
\hline OH-abstraction & $1.03 \times 10^{-25}$ & $2.12 \times 10^{-23}$ & $1.46 \times 10^{-18}$ & $1.53 \times 10^{-14}$ & $5.20 \times 10^{-13}$ & $1.28 \times 10^{-11}$ \\
\hline Overall & $1.03 \times 10^{-25}$ & $2.12 \times 10^{-23}$ & $1.47 \times 10^{-18}$ & $1.63 \times 10^{-14}$ & $6.09 \times 10^{-13}$ & $1.82 \times 10^{-11}$ \\
\hline
\end{tabular}

The overall calculated rate constants for the $\mathrm{Br}+\mathrm{H}_{2} \mathrm{O}_{2}$ for 300 and $350 \mathrm{~K}$ are $1.53 \times 10^{-18}$ and $1.03 \times 10^{-18}\left(\mathrm{~cm}^{3}\right.$ molecule $\left.\mathrm{s}^{-1}\right)$. They are 4 orders of magnitude below the experimental values given by Heneghan and Benson ${ }^{10}$ using the very-low-pressure-reactor technique $((1.3 \pm 0.45)$ $\times 10^{-14}$ and $(3.75 \pm 1.1) \times 10^{-18} \mathrm{~cm}^{3}$ molecule $\mathrm{e}^{-1} \mathrm{~s}^{-1}$, respectively). As the temperature rises, the overall rate constants increase from $10^{-18} \mathrm{~cm}^{3}$ molecule ${ }^{-1} \mathrm{~s}^{-1}$ at $300 \mathrm{~K}$ to $10^{-11} \mathrm{~cm}^{3}$ molecule $\mathrm{s}^{-1}$ ${ }^{1}$ at $2500 \mathrm{~K}$ for the $\mathrm{Br}+\mathrm{H}_{2} \mathrm{O}_{2}$ reaction and from $10^{-23} \mathrm{~cm}^{3}$ molecule ${ }^{-1} \mathrm{~s}^{-1}$ at $300 \mathrm{~K}$ to $10^{-11} \mathrm{~cm}^{3}$ molecule ${ }^{-1} \mathrm{~s}^{-1}$ at $2500 \mathrm{~K}$ for the $\mathrm{I}+\mathrm{H}_{2} \mathrm{O}_{2}$. At high temperature, calculated rate constants for the studied reactions are nearly the same $\left(3.13 \times 10^{-11}\right.$ and $1.82 \times 10^{-11} \mathrm{~cm}^{3}$ molecule ${ }^{-1} \mathrm{~s}^{-1}$ at $2500 \mathrm{~K}$ for the $\mathrm{Br}+\mathrm{H}_{2} \mathrm{O}_{2}$ and $\mathrm{I}+\mathrm{H}_{2} \mathrm{O}_{2}$ reactions, respectively). 
For the $\mathrm{Br}+\mathrm{H}_{2} \mathrm{O}_{2}$ reaction, the $\mathrm{H}$-abstraction pathway is predicted to be the major channel over the temperature range of $250-2500 \mathrm{~K}$. The most important contribution of the $\mathrm{OH}$-abstraction channel to the overall rate constant is detected at $2500 \mathrm{~K}(18 \%)$. However, the $\mathrm{OH}$-abstraction pathway is the major channel for the $\mathrm{I}+\mathrm{H}_{2} \mathrm{O}_{2}$ reaction and the largest contribution of the $\mathrm{H}$ abstraction channel to the overall rate constant is observed at $2500 \mathrm{~K}(30 \%)$. This work provide the first ab initio investigation of the $\mathrm{I}+\mathrm{H}_{2} \mathrm{O}_{2}$ reaction, there is no experimental nor theoretical study reported in the literature.

The three-parameter Arrhenius expressions obtained over the temperature range $250-2500 \mathrm{~K}$ for both studied reactions are reported in Table 10.

Table 10. Arrhenius Parameters for the $\mathrm{Br}+\mathrm{H}_{2} \mathrm{O}_{2}$ and $\mathrm{I}+\mathrm{H}_{2} \mathrm{O}_{2}$ Reactions Calculated Over the Temperature Range 250-2500 K

\begin{tabular}{|l|c|c|c|}
\hline \multicolumn{3}{|c|}{$\mathrm{Br}^{\mid}$} & $A\left(\mathrm{~cm}_{2} \mathrm{O}_{2}\right.$ \\
\hline molecule- & $n$ & $E_{a}\left(\mathrm{~kJ} \mathrm{~mol}^{-1}\right)$ \\
\hline H-abstraction & $4.68 \times 10^{-19}$ & 2.51 & 38.45 \\
\hline OH-abstraction & $1.09 \times 10^{-18}$ & 2.32 & 55.66 \\
\hline Overall & $7.39 \times 10^{-23}$ & 3.59 & 26.41 \\
\hline \multicolumn{3}{|c|}{$\mathrm{I}+\mathrm{H}_{2} \mathrm{O}_{2}$} \\
\hline H-abstraction & $3.25 \times 10^{-19}$ & 2.67 & 88.08 \\
\hline OH-abstraction & $1.91 \times 10^{-18}$ & 2.40 & 63.70 \\
\hline Overall & $3.12 \times 10^{-20}$ & 2.95 & 60.23 \\
\hline
\end{tabular}

The three-parameter Arrhenius expression fitted to the overall rate constant computed in the range $250-2500 \mathrm{~K}$ are:

$$
\begin{aligned}
& k_{\mathrm{Br}+\mathrm{H}_{2} \mathrm{O}_{2}}(T)=7.39 \times 10^{-23} \times T^{3.59} \exp \left(-26.41\left(\mathrm{~kJ} \mathrm{~mol}^{-1}\right) / \mathrm{R} T\right) \\
& k_{\mathrm{I}+\mathrm{H}_{2} \mathrm{O}_{2}}(T)=3.12 \times 10^{-20} \times T^{2.95} \exp \left(-60.23\left(\mathrm{~kJ} \mathrm{~mol}^{-1}\right) / \mathrm{R} T\right)
\end{aligned}
$$


Through the above expression, we can obtain $k_{\mathrm{Br}+\mathrm{H}_{2} \mathrm{O}_{2}}(298 \mathrm{~K})=1.38 \times 10^{-18} \mathrm{~cm}^{3}$ molecule ${ }^{-1}$ $\mathrm{s}^{-1}$ and $k_{\mathrm{Br}+\mathrm{H}_{2} \mathrm{O}_{2}}(417 \mathrm{~K})=9.67 \times 10^{-17} \mathrm{~cm}^{3}$ molecule ${ }^{-1} \mathrm{~s}^{-1}$. Our results at 298 and $417 \mathrm{~K}$ are in quite good agreement with the upper limit experimental values giving by Leu $^{8}\left(<1.5 \times 10^{-15}\right.$ and $<3.01 .5 \times 10^{-15} \mathrm{~cm}^{3}$ molecule $\mathrm{s}^{-1}$, respectively). The calculated activation energy for the reaction of $\mathrm{Br}+\mathrm{H}_{2} \mathrm{O}_{2}$ is $26.41 \mathrm{~kJ} \mathrm{~mol}^{-1}$. This result is consistent with the experimental value given by Heneghan and Benson ${ }^{10}\left(18.4 \mathrm{~kJ} \mathrm{~mol}^{-1}\right.$ in the temperature range $\left.300-350 \mathrm{~K}\right)$. Our computations show that the activation energy for the reaction of $\mathrm{I}+\mathrm{H}_{2} \mathrm{O}_{2}$ is important $(60.23$ $\mathrm{kJ} \mathrm{mol}^{-1}$ ) and higher than the value obtained for the $\mathrm{Br}+\mathrm{H}_{2} \mathrm{O}_{2}$.

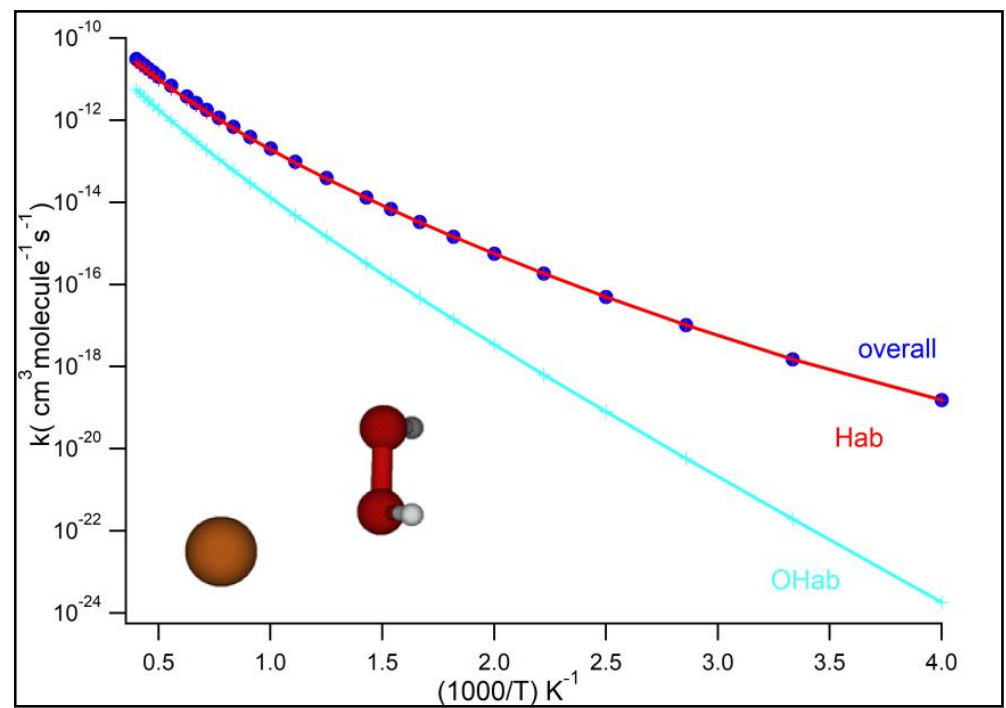

Figure 7. Thermal Rate Constants for the $\mathrm{H}$-abstraction, the $\mathrm{OH}$-abstraction, and the Overall Rate Constant for the $\mathrm{Br}+\mathrm{H}_{2} \mathrm{O}_{2}$ Reaction. 


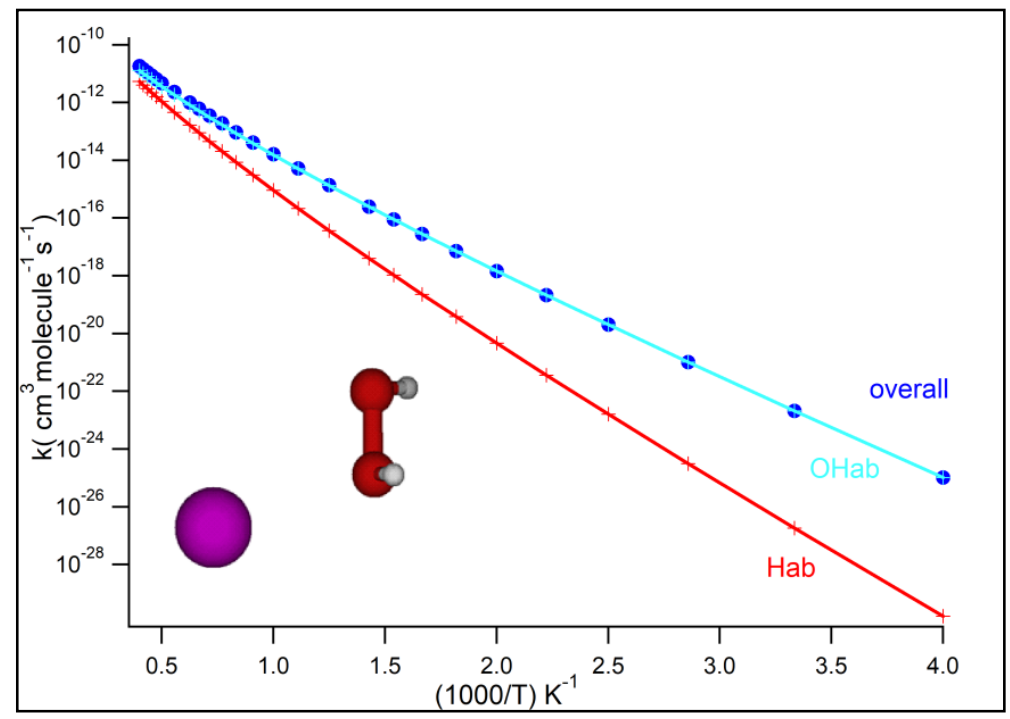

Figure 8. Thermal Rate Constants for the H-abstraction, the $\mathrm{OH}$-abstraction, and the Overall Rate Constant for the $\mathrm{I}+\mathrm{H}_{2} \mathrm{O}_{2}$ Reaction.

\section{Conclusions}

The reactivity of hydrogen peroxide with $\mathrm{Br}$ and I atoms has been studied using different approaches based on B3LYP optimization and CCSD(T)/CBS single-point energy calculations including a number of corrections (ZPE, CV,SO, and SR). For the H-abstraction channel the calculated reaction enthalpy at $298 \mathrm{~K}\left(-0.2 \mathrm{~kJ} \mathrm{~mol}^{-1}\right.$ and $67.7 \mathrm{~kJ} \mathrm{~mol}^{-1}$ for $\mathrm{Br}+\mathrm{H}_{2} \mathrm{O}_{2}$ and I + $\mathrm{H}_{2} \mathrm{O}_{2}$ reactions respectively) are in a good agreement with the available literature data ${ }^{55}(-0.3$ $\mathrm{kJ} \mathrm{mol}^{-1}$ and $67.6 \mathrm{~kJ} \mathrm{~mol}^{-1}$ for $\mathrm{Br}+\mathrm{H}_{2} \mathrm{O}_{2}$ and $\mathrm{I}+\mathrm{H}_{2} \mathrm{O}_{2}$ reactions respectively). Thermochemistry for $\mathrm{HOBr}$ and $\mathrm{HOI}$ has been revised and updated standard enthalpies of formation at $298 \mathrm{~K}$ for $\mathrm{HOBr}$ and $\mathrm{HOI}$ are the following :

$$
\Delta_{\mathrm{f}} H^{\circ}{ }_{298 \mathrm{~K}}(\mathrm{HOBr})=(-66.2 \pm 4.6) \mathrm{kJ} \mathrm{mol}^{-1} \text { and } \Delta_{\mathrm{f}} H^{\circ}{ }_{298 \mathrm{~K}}(\mathrm{HOI})=(-66.8 \pm 4.7) \mathrm{kJ} \mathrm{mol}^{-1} .
$$

The rate constants obtained with canonical transition state theory including Eckart tunneling correction are reported over a wide temperature range $(250-2500 \mathrm{~K})$. The reaction mechanism is identified as a direct hydrogen abstraction one for the $\mathrm{Br}+\mathrm{H}_{2} \mathrm{O}_{2}$ reaction and as a direct $\mathrm{OH}-$ abstraction one for the $\mathrm{I}+\mathrm{H}_{2} \mathrm{O}_{2}$ reaction. The modified Arrhenius parameters have been 
estimated for the overall reactions: $k_{\mathrm{Br}^{+} \mathrm{H}_{2} \mathrm{O}_{2}}(T)=7.39 \times 10^{-23} \times T^{3.59} \exp \left(-26.41\left(\mathrm{~kJ} \mathrm{~mol}^{-1}\right) /\right.$ $\mathrm{R} T)$ and $k_{\mathrm{I}+\mathrm{H}_{2} \mathrm{O}_{2}}(T)=3.12 \times 10^{-20} \times T^{2.95} \exp \left(-60.23\left(\mathrm{~kJ} \mathrm{~mol}^{-1}\right) / \mathrm{R} T\right)$.

\section{AUTHOR INFORMATION}

\section{Corresponding Authors}

ivan.cernusak@uniba.sk,

florent.louis@univ-lille1.fr

\section{Notes}

The authors declare no competing financial interest.

\section{ACKNOWLEDGMENTS}

Computer time for part of the theoretical calculations was kindly provided by the Centre de Ressources Informatiques (CRI) of the University of Lille1 and the Centre Régional Informatique et d'Applications Numériques de Normandie (CRIANN). Part of the calculations were also performed at the Computing Centre of the Slovak Academy of Sciences using the supercomputing infrastructure acquired in project ITMS 26230120002 and 26210120002 (Slovak infrastructure for high-performance computing) supported by the Research \& Development Operational Programme funded by the ERDF.

This work was part of the LABEX CaPPA (Chemical and Physical Properties of the Atmosphere), which is funded by the French National Research Agency (ANR) through the PIA (Programme d'Investissement d'Avenir) under contract "ANR-11-LABX-0005-01and, also supported by the Regional Council "Nord-Pas de Calais" and the "European Funds for Regional Economic Development". The authors thank also the Slovak Grant Agency VEGA (Grant 
1/0092/14) and APVV (Project APVV-15-0105). This work was performed in the frame of the international collaboration agreement between IRSN, Comenius, Lille 1, and CNRS.

\section{References}

(1) Read, K. A.; Mahajan, A. S.; Carpenter, L. J.; Evans, M. J.; Faria, B. V. E.; Heard, D. E.; Hopkins, J. R.; Lee, J. D.; Moller, S. J.; Lewis, A. C.; et al. Extensive Halogen-Mediated Ozone Destruction over the Tropical Atlantic Ocean. Nature 2008, 453 (7199), 12321235.

(2) Watson, R.; Machado, G.; Fischer, S.; Davis, D. D. A Temperature Dependence Kinetics Study of the Reactions of $\mathrm{Cl}\left({ }^{2} \mathrm{P}_{3 / 2}\right)$ with $\mathrm{O}_{3}, \mathrm{CH}_{4}$, and $\mathrm{H}_{2} \mathrm{O}_{2}$. J. Chem. Phys. 1976, 65 (6), 2126-2138.

(3) Michael, J. v.; Whytock, D. a.; Lee, J. h.; Payne, W. a.; Stief, L. j. Absolute Rate Constant for the Reaction of Atomic Chlorine with Hydrogen Peroxide Vapor over the Temperature Range 265-400 K. J. Chem. Phys. 1977, 67 (8), 3533-3536.

(4) Leu, M.-T.; DeMore, W. B. Rate Constants at $295 \mathrm{~K}$ for the Reactions of Atomic Chlorine with $\mathrm{H}_{2} \mathrm{O}_{2}, \mathrm{HO}_{2}, \mathrm{O}_{3}, \mathrm{CH}_{4}$ and $\mathrm{HNO}_{3}$. Chem. Phys. Lett. 1976, 41 (1), 121-124.

(5) Poulet, G.; Le Bras, G.; Combourieu, J. Kinetic Study of the Reactions of Cl Atoms with $\mathrm{HNO}_{3}, \mathrm{H}_{2} \mathrm{O}_{2}$, and $\mathrm{HO}_{2}$. J. Chem. Phys. 1978, 69 (2), 767-773.

(6) Keyser, L. F. Absolute Rate Constant of the Reaction between Chlorine ( $\left.{ }^{2} \mathrm{P}\right)$ Atoms and Hydrogen Peroxide from 298 to 424 K. J. Phys. Chem. 1980, 84 (1), 11-14.

(7) Marouani, S.; Koussa, H.; Bahri, M.; Hochlaf, M.; Batis, H. Ab Initio Calculation on the Rate Constants of the Reaction $\mathrm{H}_{2} \mathrm{O}_{2}+\mathrm{Cl}$. J. Mol. Struct. THEOCHEM 2009, 905 (1), 7075.

(8) Leu, M.-T. Upper Limits for the Rate Constant for the Reaction $\mathrm{Br}+\mathrm{H}_{2} \mathrm{O}_{2} \rightarrow \mathrm{HBr}+\mathrm{HO}_{2}$. Chem. Phys. Lett. 1980, 69 (1), 37-39.

(9) Posey, J.; Sherwell, J.; Kaufman, M. Kinetics of the Reactions of Atomic Bromine with $\mathrm{HO}_{2}$ and $\mathrm{H}_{2} \mathrm{O}_{2}$. Chem. Phys. Lett. 1981, 77 (3), 476-479.

(10) Heneghan, S. P.; Benson, S. W. Kinetic Study of the Reactions of $\mathrm{Cl}$ and $\mathrm{Br}$ with $\mathrm{H}_{2} \mathrm{O}_{2}$. Int. J. Chem. Kinet. 1983, 15 (12), 1311-1319.

(11) Benson, S. W.; Nangia, P. S. Some Unresolved Problems in Oxidation and Combustion. Acc. Chem. Res. 1979, 12 (7), 223-228.

(12) Vogt, R. Iodine Compounds in the Atmosphere. Springer 1999, 113-128.

(13) Vogt, R.; Sander, R.; Glasow, R. von; Crutzen, P. J. Iodine Chemistry and Its Role in Halogen Activation and Ozone Loss in the Marine Boundary Layer: A Model Study. $J$. Atmospheric Chem. 1999, 32 (3), 375-395.

(14) Saiz-Lopez, A.; Plane, J. M. C.; Baker, A. R.; Carpenter, L. J.; von Glasow, R.; Gómez Martín, J. C.; McFiggans, G.; Saunders, R. W. Atmospheric Chemistry of Iodine. Chem. Rev. 2012, 112 (3), 1773-1804.

(15) Bosland, L.; Funke, F.; Langrock, G.; Girault, N. PARIS Project: Radiolytic Oxidation of Molecular Iodine in Containment during a Nuclear Reactor Severe Accident: Part 2. Formation and Destruction of Iodine Oxides Compounds under Irradiation - Experimental Results Modelling. Nucl. Eng. Des. 2011, 241 (9), 4026-4044. 
(16) Funke, F.; Langrock, G.; Kanzleiter, T.; Poss, G.; Fischer, K.; Kühnel, A.; Weber, G.; Allelein, H.-J. Iodine Oxides in Large-Scale THAI Tests. Nucl. Eng. Des. 2012, 245 (Supplement C), 206-222.

(17) Dickinson, S.; Auvinen, A.; Ammar, Y.; Bosland, L.; Clément, B.; Funke, F.; Glowa, G.; Kärkelä, T.; Powers, D. A.; Tietze, S.; et al. Experimental and Modelling Studies of Iodine Oxide Formation and Aerosol Behaviour Relevant to Nuclear Reactor Accidents. Ann. Nucl. Energy 2014, 74 (Supplement C), 200-207.

(18) Mečiarová, K.; Cantrel, L.; Černušák, I. Thermodynamic-Data-of-Iodine-ReactionsCalculated-by-Quantum-Chemistry-Training-Set-of-Molecules.Pdf. Collect. Czechoslov. Chem. Commun. 2008, 73 (10), 1340-1356.

(19) Canneaux, S.; Xerri, B.; Louis, F.; Cantrel, L. Theoretical Study of the Gas-Phase Reactions of Iodine Atoms $\left({ }^{2} \mathrm{P}_{3 / 2}\right)$ with $\mathrm{H}_{2}, \mathrm{H}_{2} \mathrm{O}, \mathrm{HI}$, and OH. J. Phys. Chem. A 2010, 114 (34), 9270-9288.

(20) Mečiarová, K.; Šulka, M.; Canneaux, S.; Louis, F.; Černušák, I. A Theoretical Study of the Kinetics of the Forward and Reverse Reactions $\mathrm{HI}+\mathrm{CH}_{3}=\mathrm{I}+\mathrm{CH}_{4}$. Chem. Phys. Lett. 2011, 517 (4), 149-154.

(21) Louis, F.; Černušák, I.; Canneaux, S.; Mečiarová, K. Atmospheric Reactivity of $\mathrm{CH}_{3} \mathrm{I}$ and $\mathrm{CH}_{2} \mathrm{I}_{2}$ with $\mathrm{OH}$ Radicals: A Comparative Study of the H- versus I-Abstraction. Comput. Theor. Chem. 2011, 965 (2), 275-284.

(22) Šulka, M.; Šulková, K.; Louis, F.; Neogrády, P.; Černušák, I. A Theoretical Study of the X-Abstraction Reactions ( $\mathrm{X}=\mathrm{H}, \mathrm{Br}$, or I) from $\mathrm{CH}_{2} \mathrm{IBr}$ by $\mathrm{OH}$ Radicals: Implications for Atmospheric Chemistry. Z. Phys. Chem. 2013, 227 (9-11), 1337-1359.

(23) Šulková, K.; Šulka, M.; Louis, F.; Neogrády, P. Atmospheric Reactivity of $\mathrm{CH}_{2} \mathrm{ICl}$ with $\mathrm{OH}$ Radicals: High-Level OVOS CCSD(T) Calculations for the X-Abstraction Pathways (X = H, Cl, or I). J. Phys. Chem. A 2013, 117 (4), 771-782.

(24) Khanniche, S.; Louis, F.; Cantrel, L.; Černušák, I. A Density Functional Theory and Ab Initio Investigation of the Oxidation Reaction of CO by IO Radicals. J. Phys. Chem. A 2016, 120 (10), 1737-1749.

(25) Becke, A. D. Density-functional Thermochemistry. III. The Role of Exact Exchange. J. Chem. Phys. 1993, 98 (7), 5648-5652.

(26) Dunning, T. H. Gaussian Basis Sets for Use in Correlated Molecular Calculations. I. The Atoms Boron through Neon and Hydrogen. J. Chem. Phys. 1989, 90 (2), 1007-1023.

(27) Peterson, K. A.; Shepler, B. C.; Figgen, D.; Stoll, H. On the Spectroscopic and Thermochemical Properties of $\mathrm{ClO}, \mathrm{BrO}, \mathrm{IO}$, and Their Anions. J. Phys. Chem. A 2006, 110 (51), 13877-13883.

(28) Johnson III, R. D. NIST Computational Chemistry Comparison and Benchmark Database NIST Standard Reference Database Number 101; 2016.

(29) Hratchian, H. P.; Schlegel, H. B. Accurate Reaction Paths Using a Hessian Based Predictor-corrector Integrator. J. Chem. Phys. 2004, 120 (21), 9918-9924.

(30) Hratchian, H. P.; Schlegel, H. B. Theory and Applications of Computational Chemistry 1st Edition; The First 40 Years, Clifford D., G. F., Kwang K., Gustavo S., Eds. Elsevier B.V.: Amsterdam, 2005.

(31) Hratchian, H. P.; Schlegel, H. B. Using Hessian Updating To Increase the Efficiency of a Hessian Based Predictor-Corrector Reaction Path Following Method. J. Chem. Theory Comput. 2005, 1 (1), 61-69.

(32) Frisch, M. J.; Trucks, G. W.; Schlegel, H. B.; Scuseria, G. E.; Robb, M. A.; Cheeseman, J. R.; Scalmani, G.; Barone, G.; Petersson, G. .; Nakatsuji, H.; et al. Gaussian 09, Revision D.01, Gaussian, Inc.: Wallingford CT; 2016. 
(33) Werner, H.-J.; Knowles, P. J.; Knizia, G.; Manby, F. R.; Schütz, M.; Celani, P.; Györffy, W.; Kats, D.; Korona, T.; Lindh, R. Molpro, Version 2015, a Package of Ab Initio Programs.

(34) Peterson, K. A.; Dunning, T. H. Accurate Correlation Consistent Basis Sets for Molecular Core-valence Correlation Effects: The Second Row Atoms Al-Ar, and the First Row Atoms B-Ne Revisited. J. Chem. Phys. 2002, 117 (23), 10548-10560.

(35) DeYonker, N. J.; Peterson, K. A.; Wilson, A. K. Systematically Convergent Correlation Consistent Basis Sets for Molecular Core-Valence Correlation Effects: The Third-Row Atoms Gallium through Krypton. J. Phys. Chem. A 2007, 111 (44), 11383-11393.

(36) Min, S. K.; Lee, E. C.; Lee, H. M.; Kim, D. Y.; Kim, D.; Kim, K. S. Complete Basis Set Limit of Ab Initio Binding Energies and Geometrical Parameters for Various Typical Types of Complexes. J. Comput. Chem. 2008, 29 (8), 1208-1221.

(37) Douglas, M.; Kroll, N. M. Quantum Electrodynamical Corrections to the Fine Structure of Helium. Ann. Phys. 1974, 82 (1), 89-155.

(38) Hess, B. A. Applicability of the No-Pair Equation with Free-Particle Projection Operators to Atomic and Molecular Structure Calculations. Phys. Rev. A 1985, 32 (2), 756-763.

(39) Hess, B. A. Relativistic Electronic-Structure Calculations Employing a Two-Component No-Pair Formalism with External-Field Projection Operators. Phys. Rev. A 1986, 33 (6), 3742-3748.

(40) de Jong, W. A.; Harrison, R. J.; Dixon, D. A. Parallel Douglas-Kroll Energy and Gradients in NWChem: Estimating Scalar Relativistic Effects Using Douglas-Kroll Contracted Basis Sets. J. Chem. Phys. 2000, 114 (1), 48-53.

(41) Davidson, E. R.; Ishikawa, Y.; Malli, G. L. Validity of First-Order Perturbation Theory for Relativistic Energy Corrections. Chem. Phys. Lett. 1981, 84 (2), 226-227.

(42) Dixon, D. A.; de Jong, W. A.; Peterson, K. A.; Christe, K. O.; Schrobilgen, G. J. Heats of Formation of Xenon Fluorides and the Fluxionality of $\mathrm{XeF}_{6}$ from High Level Electronic Structure Calculations. J. Am. Chem. Soc. 2005, 127 (24), 8627-8634.

(43) Dixon, D. A.; Grant, D. J.; Christe, K. O.; Peterson, K. A. Structure and Heats of Formation of Iodine Fluorides and the Respective Closed-Shell Ions from CCSD(T) Electronic Structure Calculations and Reliable Prediction of the Steric Activity of the Free-Valence Electron Pair in $\mathrm{ClF}_{6}{ }^{-}, \mathrm{BrF}_{6}{ }^{-}$, and $\mathrm{IF}_{6}{ }^{-}$. Inorg. Chem. 2008, 47 (12), 54855494.

(44) Khudyakov, I. V.; Serebrennikov, Y. A.; Turro, N. J. Spin-Orbit Coupling in Free-Radical Reactions: On the Way to Heavy Elements. Chem. Rev. 1993, 93 (1), 537-570.

(45) Jasper, A. W.; Klippenstein, S. J.; Harding, L. B. The Effect of Spin-Orbit Splitting on the Association Kinetics of Barrierless Halogen Atom-Hydrocarbon Radical Reactions. J. Phys. Chem. A 2010, 114 (18), 5759-5768.

(46) Eyring, H. The Activated Complex in Chemical Reactions. J. Chem. Phys. 1935, 3 (2), $107-115$.

(47) Beckey, H. D. H. S. Johnston: Gas Phase Reaction Rate Theory. The Ronald Press Company, New York 1966. 362 Seiten. Preis: Geb. \$ 10.-. Ber Bunsenges. Phys. Chem. 1966, 71 (5), 535-536.

(48) Laidler, K. J. Theories of Chemical Reaction Rates; New York : McGraw-Hill, 1969.

(49) Eckart, C. The Penetration of a Potential Barrier by Electrons. Phys. Rev. 1930, 35 (11), 1303-1309.

(50) Miyoshi, A. GPOP Software.

(51) Moore, C. E. Atomic Energy Levels, USGPO, Vols II and III. NSRDS-NBS 35: Washington, DC. 1971. 
(52) Nicklass, A.; Peterson, K. A.; Berning, A.; Werner, H.-J.; Knowles, P. J. Convergence of Breit-Pauli Spin-orbit Matrix Elements with Basis Set Size and Configuration Interaction Space: The Halogen Atoms F, Cl, and Br. J. Chem. Phys. 2000, 112 (13), 5624-5632.

(53) Feller, D.; Peterson, K. A.; de Jong, W. A.; Dixon, D. A. Performance of Coupled Cluster Theory in Thermochemical Calculations of Small Halogenated Compounds. J. Chem. Phys. 2003, 118 (8), 3510-3522.

(54) Šulková, K.; Federič, J.; Louis, F.; Cantrel, L.; Demovič, L.; Černušák, I. Thermochemistry of Small Iodine Species. Phys. Scr. 2013, 88 (5), 058304.

(55) Stevens, J. E.; Cui, Q.; Morokuma, K. An Ab Initio Investigation of Spin-Allowed and Spin-Forbidden Pathways of the Gas Phase Reactions of $\mathrm{O}\left({ }^{3} \mathrm{P}\right)+\mathrm{C} 2 \mathrm{H}_{5} \mathrm{I}$. J. Chem. Phys. 1998, 108 (4), 1544-1551.

(56) Burkholder, J. B.; Sander, S. P.; Abbatt, J.; Barker, J. R.; Huie, R. E.; Kolb, C. E.; Kurylo, M. J.; Orkin, V. L.; Wilmouth, D. M.; Wine, P. H. Chemical Kinetics and Photochemical Data for Use in Atmospheric Studies, Evaluation No. 18, JPL Publication 15-10, Jet Propulsion Laboratory, Pasadena, 2015; 2015.

(57) Ruscic, B.; Berkowitz, J. Experimental Determination of $\Delta \mathrm{H}_{\mathrm{f}}^{0}(\mathrm{HOBr})$ and Ionization Potentials (HOBr): Implications for Corresponding Properties of HOI. J. Chem. Phys. 1994, 101 (9), 7795-7803.

(58) Hassanzadeh, P.; Irikura, K. K. Nearly Ab Initio Thermochemistry: The Use of Reaction Schemes. Application to IO and HOI. J. Phys. Chem. A 1997, 101 (8), 1580-1587.

(59) Lock, M.; Barnes, R. J.; Sinha, A. Near-Threshold Photodissociation Dynamics of HOBr: Determination of Product State Distribution, Vector Correlation, and Heat of Formation. J. Phys. Chem. 1996, 100 (19), 7972-7980.

(60) Denis, P. A. Thermochemistry of the Hypobromous and Hypochlorous Acids, $\mathrm{HOBr}$ and HOCl. J. Phys. Chem. A 2006, 110 (17), 5887-5892.

(61) Berry, R. J.; Yuan, J.; Misra, A.; Marshall, P. Experimental and Computational Investigations of the Reaction of $\mathrm{OH}$ with $\mathrm{CF}_{3} \mathrm{I}$ and the Enthalpy of Formation of HOI. $J$. Phys. Chem. A 1998, 102 (27), 5182-5188. 